Dear Author,

Please, note that changes made to the HTML content will be added to the article before publication, but are not reflected in this PDF.

Note also that this file should not be used for submitting corrections. 


\title{
Modern viticulture in southern Europe: Vulnerabilities and strategies for adaptation to water scarcity
}

\author{
Q1 J.M. Costa ${ }^{\mathrm{a}, \mathrm{b}, *}$, M. Vaz ${ }^{\mathrm{c}}$, J. Escalona ${ }^{\mathrm{d}}$, R. Egipto ${ }^{\mathrm{b}}$, C. $_{\text {Lopes }}{ }^{\mathrm{b}}$, H. Medrano $^{\mathrm{d}}$, M.M. Chaves $^{\mathrm{a}, \mathrm{b}}$ \\ a LEM-ITQB, UNL, Apartado 127, 2780-901 Oeiras, Portugal \\ ${ }^{\mathrm{b}}$ LEAF- ISA, Tapada da Ajuda, 1349-017 Lisboa, Portugal \\ ' ICAAM, Univ. Évora, 7002-554 Évora, Portugal \\ d Grup de Recerca en Biologia de les Plantes en Condicions Mediterrànies, Dep. Biologia, Univ. de les Illes Balears, 07122 Palma de Mallorca, Spain
}

\section{A R T I C L E I N F O}

\section{Article history:}

Received 1 May 2015

Received in revised form 19 August 2015

Accepted 25 August 2015

Available online $\mathrm{xxx}$

\section{Keywords:}

Mediterranean

Grapevine stress physiology

Sustainable water use in the vineyard and winery

Environmental impact

Water management

Water metrics and water use indicators

\begin{abstract}
A B S T R A C T
Water is now considered the most important but vulnerable resource in the Mediterranean region. Nevertheless, irrigation expanded fast in the region (e.g. South Portugal and Spain) to mitigate environmental stress and to guarantee stable grape yield and quality. Sustainable wine production depends on sustainable water use in the wine's supply chain, from the vine to the bottle. Better understanding of grapevine stress physiology (e.g. water relations, temperature regulation, water use efficiency), more robust crop monitoring/phenotyping and implementation of best water management practices will help to mitigate climate effects and will enable significant water savings in the vineyard and winery. In this paper, we focused on the major vulnerabilities and opportunities of South European Mediterranean viticulture (e.g. in Portugal and Spain) and present a multi-level strategy (from plant to the consumer) to overcome region's weaknesses and support strategies for adaptation to water scarcity, promote sustainable water use and minimize the environmental impact of the sector.
\end{abstract}

(c) 2015 Published by Elsevier B.V.

\section{The wine grape industry in south Mediterranean Europe}

World's wine production are located in a wide geographical and climatic range, often in mid-latitude regions characterized by climate variability and stressful environments, such as the Mediterranean region (Fraga et al., 2013; Lionello et al., 2014). The European Union (EU-28), is the world's leader in wine production with about $50 \%$ of world's vine-growing area and about $60 \%$ of total volume of production (USDA, 2014). France, Italy, Spain, Germany and Portugal are the five leading EU wine producers and altogether they represent $90 \%$ of EU production (USDA, 2014). Spain has the largest vineyard area in the world (950,541 ha in 2014) with an increasing irrigated area (36\% of the total, in 2014) (MAGRAMA, 2014) (Fig. 1). Portugal is the EU's 5th largest wine producer with a total of $6.7 \mathrm{Mhl}$ in 2013 and it has a cultivated area estimated to be about 224,000 ha (IVV, 2015). In 2010, the irrigated area was estimated in $15 \%$ of the total area of vineyards (INE, 2010). However, irrigation continued expanding in the recent years in Portugal, in particular in the Alentejo region, and presently, the percentage of irrigated vines should be slightly higher and around $20 \%$.

\footnotetext{
* Corresponding author.

E-mail address: miguelc@itqb.unl.pt (J.M. Costa).
}

Mediterranean fresh water resources are under high pressure due to fast-growing population, increased water scarcity, extreme climate variability and intensive water use in agriculture, industry and tourism activities (Lange et al., 2005; Costa et al., 2007; EEA, 2012a,b; Lereboullet et al., 2013a,b; Blum, 2014). Water is now considered by EU experts as the most important but vulnerable resource in the Mediterranean region (EU-ERANETMED, 2014). In addition, climate scenarios for South Mediterranean Europe are not favourable for agriculture. The predicted lower precipitation, higher air and soil temperatures, more frequent and longer extreme climate events (e.g. heat waves, extreme drought) (IPCC, 2013) will negatively affect viticulture in the region (Chaves et al., 2010; Rogiers and Clarke, 2013; Teskey et al., 2014; Lionello et al., 2014).

In Europe, irrigation of vineyards is below $10 \%$ of the total area, but the tendency towards irrigation is increasing to mitigate the effects of climate change and more stressful environment. Irrigation has therefore expanded in dry regions of France, Spain, Portugal and Italy (Intrigliolo and Castel, 2008; Seguin, 2010; USDA, 2013; Fraga et al., 2013; Barisan et al., 2014; De Leo et al., 2015). Meanwhile, agriculture in South Mediterranean Europe is increasingly subjected to more restrictive legislation at both EU and individual country levels namely in terms of water use regulation and water conservation. Next we present some of the major 


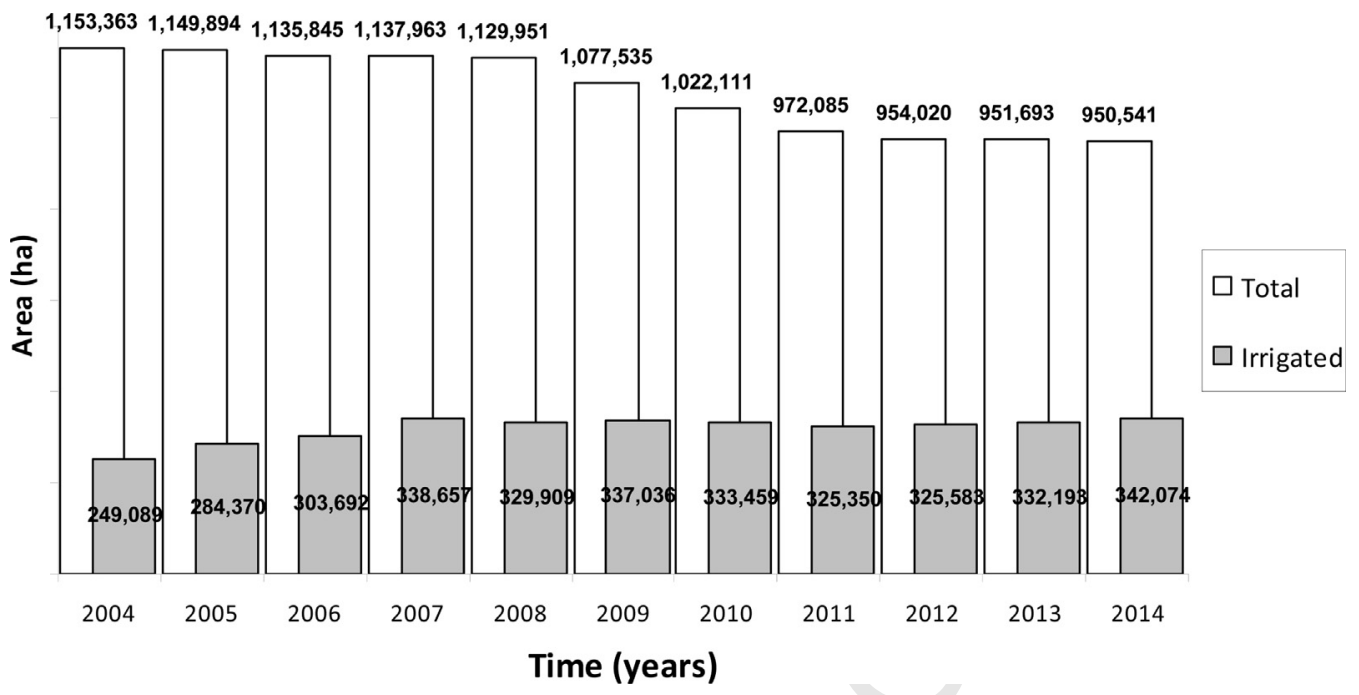

Fig. 1. Total cultivated area (ha) and irrigated area (ha) of Spanish vineyards from 2004 to 2014. Source: “Encuesta sobre Superficies y Rendimientos de cultivos en España, ESYRCE, Spanish Agriculture Ministry 2014.

constrains and opportunities experienced by South European wine industry, focusing on Spain and Portugal.

\subsection{Constraints (environment and socio-economic)}

An important vulnerability of rainfed agriculture in the Mediterranean is the combination of high air temperature and water deficit coupled to marked inter-annual and intra-annual climate variability and scarce water resources (Costa et al., 2007; Lopes et al., 2014; Rogiers and Clarke, 2013; Valverde et al., 2015). In the case of Vitis vinifera, Mediterranean climate may limit yield and berry quality because most of the berry growth and ripening period occurs under conditions of high air temperature and soil water deficit (Medrano et al., 2003; Chaves et al., 2007, 2010; Lereboullet et al., 2013a,b; 2014). In rainfed Mediterranean viticulture, water stress can be particularly severe during summer mainly if previous winter and spring seasons are dry just. This situation is often reported for the Mediterranean zones of the Iberian Peninsula (e.g. Alentejo wine region in years 2003 and 2005). Moreover, Mediterranean viticulture is increasingly exposed to climate extremes (e.g. maximum temperatures and heat waves) (EASAC, 2013; Fraga et al., 2013; Hannah et al., 2013; Lereboullet et al., 2013a,b; Lionello et al., 2014). Not only extreme air temperatures but also high soil temperatures can be potentially negative for berry and leaf/canopy physiology. In fact, soil temperature $\left(T_{\mathrm{s}}\right)$ in Southern European countries can easily reach values above $50^{\circ} \mathrm{C}$ along the day (Fig. 2). High soil temperature not only influences root activity and root growth but also negatively impacts leaf/canopy photosynthesis, as well as diurnal and nocturnal stomatal conductance (Rogiers and Clarke, 2013). Temperature determines berry composition and quality by influencing the ripening process, berry biochemistry and synthesis/degradation of certain compounds such as anthocyanins or polyphenols (Mori et al., 2007; Teixeira et al., 2013; Zarrouk et al., 2014). High berry temperatures $\left(>35^{\circ} \mathrm{C}\right)$ may inhibit anthocyanins synthesis and induce their degradation (Bergqvist et al., 2001; Spayd et al., 2002).

Portugal is relatively well endowed in terms of water resources. However, these resources are unevenly distributed with marked difference between the rainy and cooler North and central Atlantic regions of the country and the dry and warmer South, inland regions (e.g. Alentejo). The same occurs with Spain which presents large differences in terms of water reserves and precipitation between the Atlantic and Northern regions and the southern Mediter- ranean regions. In Portugal, irrigated viticulture expanded mostly in the southern part of the country (Península de Setúbal, Alentejo, Algarve) but now other wine regions (e.g. Tejo, Douro Superior) are also now being punctually irrigated to face more stressful summer conditions (Fraga et al., 2013; Lopes et al., 2014). Spanish vineyards have been traditionally dry-farmed because irrigation was forbidden by law until 1996. Nowadays, irrigation is still not permitted in most of the "Denominaciones de Origen (DO)", and just like in Portugal, irrigation is only allowed under specific circumstances and after the technical allowance from Regional wine Commissions. However, vineyards in areas out of the DO control can be irrigated without any restriction. Although irrigation has increased dramatically in Spanish viticulture (Fig. 1), there are still authors questioning whether this is an environmentally sustainable trend in semi-arid areas such as regions of central and southern Spain (Intrigliolo and Castel, 2008; Romero et al., 2010; Medrano et al., 2015).

Ground water resources in the Mediterranean also deserve more attention. Indeed, they contribute to $20-100 \%$ of the water used in European irrigated farms, depending on the region and country. Besides the ongoing climate change is expected to limit recharge of aquifers due to reduced precipitation and to increased water abstraction to support larger irrigation needs and to minimize the problem of lower quality surface waters (Costa et al., 2007; Goderniaux et al., 2009; Stigter, 2012; Baudron et al., 2014; Carreira et al., 2014). Also, in most of the EU countries, groundwater users pay no tariff to water authorities and only few countries (France, Netherlands, Denmark, England and Wales) do charge a water abstraction fee (OECD, 2010).

Vulnerability and adaptive capacity of the Mediterranean viticulture is also linked to socio-economical aspects (Strano et al., 2013; Lereboullet et al., 2012; 2013a,b). For example, the small size of most of the companies results in limited budgets and restricted innovation with limited capacity to accommodate new legislation requirements for environment or new market trends related to quality (ECOPROWINE, 2014). In addition, fluctuations in the wine markets poses a limitation to Mediterranean viticulture and affect mostly smaller companies. Another limitation is the lack of information and perception of risks by growers and managers of smaller companies which restrict changes in terms of adoption of novel agronomic strategies or technologies to mitigate climate change and respond to changes in consumer demand and to more restrictive legislation on water use. 

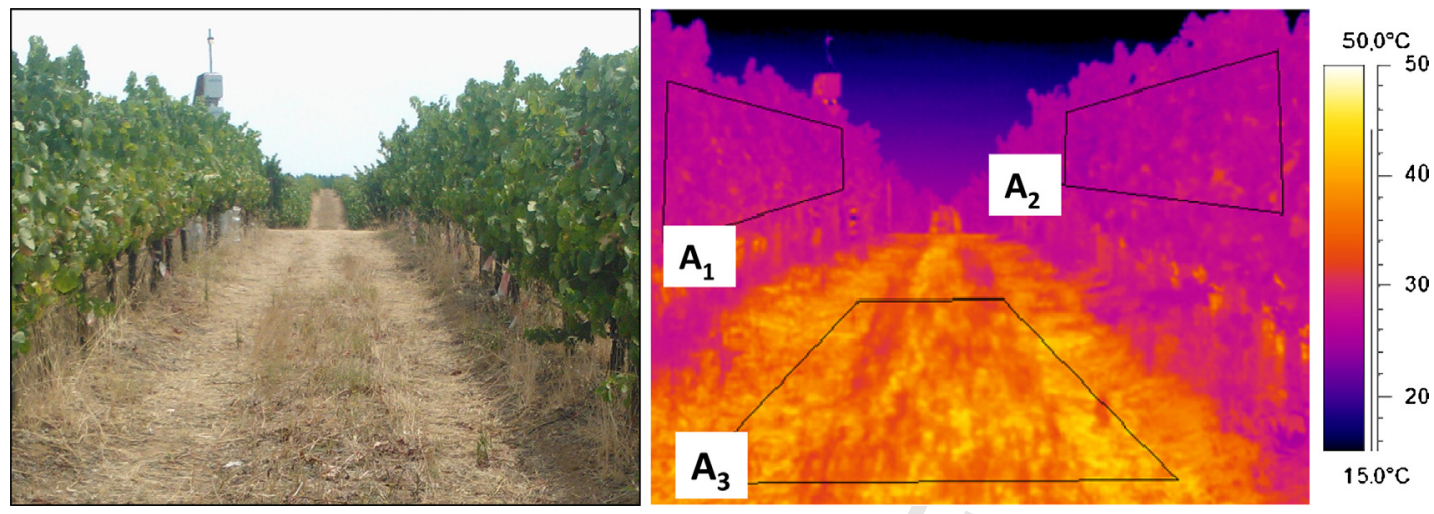

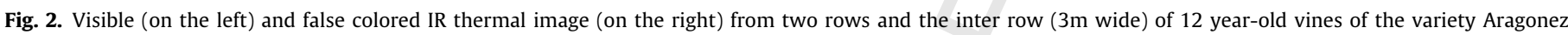

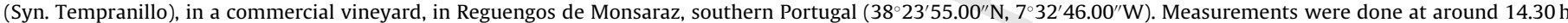

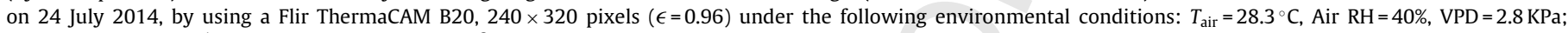

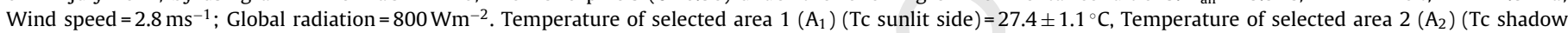
side $)=26.8 \pm 1.1^{\circ} \mathrm{C}$, Temperature of selected area $3\left(A_{3}\right)$ (soil surface) $=37.1 \pm 2.5^{\circ} \mathrm{C}$.

The lack of labour force can also be a problem in certain Mediterranean wine regions and therefore the use of emigrant labour force became common in Spain, Portugal or France following the trends observed in other intensive production agricultural systems (greenhouse horticulture) (FAO, 2013; Costa et al., 2014). Lack of statistical information concerning water use and management in the Mediterranean hinders proper policy decision on aquifer management, irrigation, pollution emissions from either surface or subsurface (Albiac, 2005; EEA, 2012a). In fact, we may still find data collections and assessments with large data gaps, lack of harmonization in estimation and data quality assurance methodologies (EEA, 2012a).

\subsection{Opportunities}

Regarding the opportunities for Mediterranean viticulture, the large historical and cultural relevance of the crop and related activities is particularly visible in Spain and Portugal, where the crop is being cultivated for centuries. This results in a large cultural tradition, available empirical knowledge, variety selection and large diversity of autochthonous varieties (Tapia et al., 2007; Gonçalves and Martins, 2015; Fraga et al., 2015). Portugal has a large genetic variability which has been stored in a network of both commercial and public vineyards. Recent set of actions were taken by the Portuguese Association for Grapevine Diversity (PORVID) to safeguard such genetic heritage and organize Portuguese biodiversity. A prospection and conservation project has been carried out with the principal objective of building a full-diversity in vivo library of the Portuguese grapevine heritage (Martins, 2011; Gonçalves and Martins, 2015). Similarly over the last few years, many regions of Spain have developed several projects focused on the prospection, characterisation and conservation of autochthonous varieties. The "Instituto Madrileño de Desarrolo Agrario" (IMIDRA) takes care of the official ampelographic collection of grapevines in Spain, and coordinates most of these projects.

The production of premium and super-premium wines give an Iberian viticulture a competitive advantage over other worldwide competitors. The multiplicity of genotypes and "terroirs" makes the Iberia Peninsula a unique region for wine production and has generated a large number of high quality vintage wines that had won several accolades worldwide. The multiple South European Mediterranean “terroirs” (e.g. Vinhos Verdes, Douro, Dão, Alentejo, Rias Baixas, Rioja, Ribera de Duero, Balearic Islands) and specific varieties (e.g. the Touriga Nacional, or the "Tempranillo") make it possible to create unique monovarietal wines or novel blends with particular tastes and aromas, which gives major competitive advantage to the Mediterranean wine sector.

Wine industry is one of the most innovative sub sectors of the EU agribusiness and there is a strong commitment of the EU translated into major investments in research and technology with a clear focus on sustainable viticulture. This is the case of major EU financed projects related to the wine sector such as EU-INNOVINE or ECOPROWINE. Additionally, cooperation between the Universities and private companies is also being promoted by EU projects. In parallel, Portuguese and Spanish authorities are promoting the image of Iberian wines abroad which permitted to increase exports and guarantee higher financial income for both countries (USDA, 2013; MAGRAMA, 2014; IVV, 2015). Finally, the increase in multiple and more demanding export markets is putting pressure on Portuguese and Spanish wine industry forcing local vineyards and wineries to a higher commitment on more environmentally sustainable practices, similarly to what is occurring in other important wine regions worldwide (Sinha and Akoorie, 2010; Berghoef and Dodds, 2011; CWSA, 2011; Retallack 2012, 2013; Gerling 2015; De Leo et al., 2015; Radke et al., 2015) or to other horticultural commodities (Torrellas et al., 2013; FAO, 2013).

\section{Advances in the understanding of grapevine responses to heat stress and drought}

\subsection{Stomata, leaf temperature and water use efficiency}

Tolerance/resistance to drought and heat stress involves combination of several traits and mechanisms that can be morphoanatomical, physiological and hydraulic (Chaves et al., 2010; Carvalho et al., 2015). Understanding the physiology and biochemistry related to stomatal regulation and their response to abiotic stress (e.g. drought) is crucial to understand plant responses to the environment and to improve plant water relations and WUE (Roelfsema and Kollist, 2013; Tsegay et al., 2014). Besides, stomatal regulation in grapevine varies with the genotype (Costa et al., 2012; Tomás et al., 2014a) and identically, we find large intra-specific variability for intrinsic WUE (Bota et al., 2001; Gaudillère et al., 2002; Koundouras et al., 2008; Rogiers et al., 2011; Tomás et al., 2012).

Improved WUE can result in water savings at both plant and crop levels, but scaling-up from single leaves to crop is not a straightforward process (Medrano et al., 2015). In fact, previous research showed that improvements in leaf-level WUE may not always translate into higher crop WUE or higher yield (Condon et al., 2004). Actually, WUE is a complex multi-trait phenotype 
related with stomatal control and also with leaf structure, leaf biochemistry and leaf diffusive properties (e.g. mesophyll conductance) (Tomás et al., 2014b; Gago et al., 2015). Differences in WUE behaviour between grapevine genotypes/varieties depend on other traits such as hydraulic and hormones as reported for model and crops species (Matzner and Comstock, 2001; Pantin et al., 2013; Torrez Ruiz et al., 2014).

In parallel with studies on WUE, a better comprehension of how plants regulate their leaf/canopy temperature in relation to stomatal behavior is equally relevant to improve adaptation/resistance to longer periods of heat and drought stress. Grapevine is considered a drought resistant species due to an efficient control of stomatal aperture in response to soil and air water deficits (Chaves et al., 2010; Costa et al., 2012). This behavior can be a protective strategy against excessive water loss and xylem cavitation (Chaves et al., 2010; Lovisolo et al., 2010) but such stomatal phenotype can also result in reduced evaporative cooling and consequent abnormal increase of leaf temperature $\left(T_{\text {leaf }}\right)$ under extreme conditions (high air temperatures and soil water deficits). In fact, under typical South Europe Mediterranean conditions (e.g. Alentejo Portuguese wine region, South Portugal), canopy temperatures can easily reach values largely above the range considered optimum for grapevine photosynthesis $\left(25-30^{\circ} \mathrm{C}\right.$ ) (Costa et al., unpublished results). Extended periods of supra-optimal temperatures can give rise to damage in the photosynthetic apparatus with negative effects on WUE (Sinclair et al., 1975; Tambussi et al., 2007). According to Sinclair et al. (1975) this may occur via: (1) an increase in transpiration due to the exponential increase in saturated water vapor density inside the leaf that increases water vapor gradient between the leaf and the outside air; (2) an increase in leaf respiration rates as $T_{\text {leaf }}$ increases, with negative effect on net $\mathrm{CO}_{2}$ assimilation. Tambussi et al. (2007) states that for cereal crops a potential gain in instantaneous WUE $\left(\mathrm{WUE}_{\text {instantaneous }}=A_{\mathrm{N}} / E\right)$ at leaf level may be less marked when the decrease in stomatal conductance to water vapour is linked to higher $T_{\text {leaf }}$ and thus increased transpiration per stomatal conductance unit (Condon et al., 2002). Tambussi et al. (2007) also states that an increased $T_{\text {leaf }}$ could induce penalties in yield and eventually in WUE $\mathrm{E}_{\text {yield }}$ in situations where evaporative cooling effect of transpiration is important (Reynolds et al., 2001). Therefore, higher $T_{\text {leaf }}$ and boundary layer effect may pose limitations to the 'scaling-up' of WUE from leaf to crop level. For instance, it has been pointed out that modern irrigation systems in which mild to moderate water stress is applied (improving WUE by partial stomatal closing) could have a lower effect than expected in crops with dense canopies (Kang and Zhang, 2004), this can partly apply in the case of $V$. vinifera.

Finally, high $T_{\text {leaf }}$ can result in accelerated leaf senescence with accelerated leaf abscission, which in the case of grapevines grown in hot climates could end in quality and yield losses due to overexposure of berries to light. Therefore, breeding and selection of grapevine for typical Mediterranean semi-arid conditions should focus on a compromise between high WUE and leaf cooling (Chaves et al., 2010; Costa et al., 2012).

\subsection{Morpho-hydraulics and water transport}

Leaf hydraulics is a key component of plants adaptation strategy in response to the environment. Recent studies in grapevine showed that hydraulic conductivity of leaves $\left(K_{\text {leaf }}\right)$ and of stem $\left(K_{\text {stem }}\right)$ contributes to variation among varieties regarding their response to soil water deficit and the recovery response to drought (Schultz and Stoll, 2010; Coupel-Ledru et al., 2014; Hochberg et al., 2015; Martorell et al., 2015). The observed intra-specific variation in $K_{\text {leaf }}$ can reflect differences in leaf morpho-anatomy (Nardini et al., 2012) and in water pathways through the outside xylem to the water evaporation sites. Contrary to water transport systems, leaf vein systems show great variation in arrangement, density, vascular bundle features and xylem conduits within the bundles (Sack and Scoffoni, 2012). In grapevine, leaf water movement suggested to be influenced by mesophyll architecture which contributes to water flux in the mesophyll and water evaporation at the cell wall surface (Tomás, 2012; Flexas et al., 2013). On the other hand, Martorell et al. (2015) found in two V. vinifera cultivars (Tempranillo and Grenache) that leaf vulnerability at $50 \%$ and $80 \%$ loss of $K_{\text {leaf }}$ (P50 and P80) as well as the maximum $K_{\text {leaf }}$ decreased seasonally by more than $20 \%$. However, $K_{\text {leaf }}$ plasticity along leaf lifespan was different between the two cvs. Only the cv Tempranillo showed an increase of $K_{\text {leaf }}$ at $-2 \mathrm{MPa}$ in the months of June and July, while Jones and Grant (2015) osmotic potential at full turgor was lower in Tempranillo than in Grenache. They showed as well that leaf resistance to hydraulic dysfunction is cultivar dependent and also a seasonal plastic trait that can be mediated by osmotic adjustment (Martorell, 2014; Martorell et al., 2015).

Regarding root traits, root hydraulics and morphology are two determinant traits influencing grapevine water relations. Higher hydraulic conductivity correlates well with higher drought tolerance of grapevine rootstocks (Schultz, 2003; Zufferey et al., 2011; Tramontini et al., 2013; Serra et al., 2014). Vigorous rootstocks showed larger hydraulic conductivity of fine roots, which is partly attributed to aquaporin expression and activity (Gambetta et al., 2013).

Root system morphology (root distribution and depth) depends on the interaction between the rootstock genotype and the surrounding environment (soil texture, bulk density and salinity, water and nitrogen availability, planting density and climatic conditions) (Koundouras, 2008). Grapevine roots have larger xylem vessels than those of stems, which causes them to be more prone to xylem cavitation (Lovisolo et al., 2008). It has been suggested that the adjusting capacity of roots to supply water relative to shoot transpiration demand is a major means for woody perennial plants to tolerate drought and it is often expressed as changes in leaf to root area ratio (Alsina et al., 2011). Different combinations of xylem vulnerability to cavitation with stomatal kinetics results in multiple degrees of isohydry/anisohydry in various plant species/cultivars (Tombesi et al., 2014). These authors suggest that $V$. vinifera near-isohydric and anisohydric genotypes differ in terms of xylem vulnerability to cavitation as well as in terms of petiole hydraulic conductivity, and that coordination of these traits results in different stomatal responses under water stress conditions. More recent findings on roots point out to the contribution of root-associated bacterial microbiome to grapevine adaptation to water stress by via increased root biomass and improved water absorption capacity (Rolli et al., 2014). This alternative way to promote drought resistance in grapevine demands more research to better comprehend the effects of soil microbiology on grapevine performance against stress.

\subsection{Hormones and metabolites}

Contrary to hydraulic signals, the role of biochemical signals in stomatal regulation is well described (Schroeder et al., 2001; Chaves et al., 2003; Pantin et al., 2013; Carvalho et al., 2015). Chemical signals with origin in roots are particularly important for grapevine adaptation to water especially at the early stages of stress (Schachtman and Goodger, 2008; Dodd, 2009; Tsegay et al., 2014; Tardieu et al., 2015). Cultivar-specific differences in stomatal control in response to drought have been attributed to differences in abscisic acid signaling and perception machinery (Soar et al., 2006; Perrone et al., 2012) and/or as a consequence of different patterns of aquaporins expression and/or activation (Vandeleur et al., 2009; Perrone et al., 2012; Pou et al., 2013). 
More recent studies point out the relevance of certain metabolites (e.g. polyols) in the adaptation to drought in grapevine. The impact of polyols on grape berry composition and plant response to water deficit was described for the variety Tempranillo grown in greenhouse and field conditions (Conde et al., 2015). Both sorbitol and mannitol limited size reduction of berry cells under drought (Conde et al., 2015). The authors suggested that grapevine cultivars which accumulate polyols as a tolerance mechanism to drought stress might have adaptive advantages under unfavourable growing conditions as they would require less water along the season to sustain yield and berry quality (Conde et al., 2015). It was also suggested that synthesis, transport and accumulation of sugar alcohols may work as bioindicators of plant health and acclimation and can be used as potential biomarkers in crop breeding (Merchant and Richter, 2011; Conde et al., 2015).

\subsection{Stress-recovery responses}

An important component of the studies on plant stress responses is the analysis and comprehension of the efficacy and related underlying mechanisms involved in recovery from water stress following rehydration (Flexas et al., 2009; Bondada and Shutthanandan, 2012; Pou et al., 2012; Sapeta et al., 2013). Fast and efficient recovery from water stress is a key characteristic of the species/genotype adaptation to changing soil and air meteorological conditions (Perrone et al., 2012; Torrez Ruiz et al., 2014). This is highly relevant to understand grapevine capacity to overcome/recover from water stress after a rainfall event and when subjected to deficit irrigation in which successive cycles of water stress/recovery are imposed to vines (Pou et al., 2008; Lopes et al., 2014). Plant's carbon balance during water stress and recovery cycles depends on the velocity and degree of photosynthetic recovery as well as on the degree and velocity of the photosynthetic decline during water depletion (Flexas et al., 2006). Plants subjected to severe water stress recover only $40-60 \%$ of their maximum photosynthesis rate during the first day after re-watering and maximum photosynthesis rates are often not recovered (Gallé and Feller, 2007; Pou et al., 2008). The severity of the previous water stress was shown to have a major influence on the velocity and extent of photosynthesis recovery in different species (Miyashita et al., 2005) including grapevine (Gómez-del-Campo et al., 2007; Pou et al., 2008; Flexas et al., 2009). Recovery of photosynthetic capacity after drought depends on restored xylem function although few data on grapevine exist to elucidate this type of coordination (Martorell, 2014). Knipfer et al. (2014) showed that responses to drought and recovery capacity involved the maintenance/recovery of xylem transport capacity in coordination with root pressure as well as leaf gas exchange responses. More research at molecular level on water stress recovery in grapevine is needed to explain grapevines' genetical variability on hydraulic and leaf gas exchange traits in response to drought stress (Perrone et al., 2012; CoupelLedru et al., 2014).

\section{Agronomic strategies in modern viticulture in dry areas}

\subsection{Water saving strategies}

Irrigation is one of the most effective tools to manipulate berry yield and quality in dry areas (Costa et al., 2007; Romero et al., 2010; Forbes et al., 2009; Flexas et al., 2009, 2010). Deficit irrigation (DI) based on the application of water below the water losses by the crop, has been largely pointed out as a reliable technique to improve water savings and productivity in grapevine (Santos et al., 2003; Chaves et al., 2007; Medrano et al., 2003, 2015). The strategy involves soil drying and re-wetting cycles with varying frequencies and intensities during the growing cycle and is deliberately used to enhance crop WUE (Dodd et al., 2009). A specific case of deficit irrigation is partial root drying (PRD). Typically, in the PRD strategy one part of the root zone is irrigated at a time, with the wet and dry parts of the root system being periodically alternated to increase ABA signalling transiently and/or prevent excessive soil drying diminishing the transport of chemical signals to the shoot (Kang and Zhang, 2004; Dodd, 2009). PRD resulted in higher WUE, water savings and improved berry quality in grapevine (Santos et al., 2003; Souza et al., 2005). However, the PRD strategy involves more complex management and higher installation costs (e.g. double amount of irrigation tubes), making it less adequate for commercial use. Besides literature presents contrasting results for PRD, as function of the soil characteristics and genotype (Santos et al., 2003; Romero et al., 2012) Table 1.

Although the general effects of deficit irrigation are well described in literature (Chaves et al., 2007; Dodd, 2009; Flexas et al., 2010), it is still not fully covered how different genotypes perform in response to mild to severe water stress in combination with particular soil and atmospheric conditions. Genotypic heterogeneity of $V$. vinifera species forces growers and farm managers to look more carefully to the water use traits of the cultivars growing in their farms in order to tune water irrigation volumes in the different plots of the vineyard. In addition, the interaction between genotype and the rootstock and their compatibility is a highly relevant issue with major consequences for plant hydraulics and water transport, and thus, for stress resistance (Gökbayrak et al., 2007; Serra et al., 2014).

The water reuse option can be considered as a cost-effective solution for Mediterranean agriculture. Water reuse reduces the need to develop new water resources and provides an adaptive solution to climate change and it has the advantage of valorising the social and environmental value of water by enhancing water resources availability and minimising wastewater outflow with additional environmental benefits (Lazarova et al., 2001; MED-EUWI, 2007; Raso, 2013). In many of the arid and semi-arid regions of the Mediterranean, recycled wastewater is being used as an affordable alternative resource for agricultural, industrial and urban non-potable purposes (Lazarova et al., 2001; Angelakis and Gikas, 2014). In countries like Australia and Israel, the use of recycled water is proving to be a viable alternate source of water for irrigation of crops (Angelakis and Gikas, 2014). The potential benefit can even be larger in case the wastewater treatment facilities are also expanded and optimized. Currently in Spain, $408 \mathrm{hm}^{3} /$ year are reused (13\% of total available water) of which $79 \%$ are for agricultural irrigation $\left(320 \mathrm{hm}^{3} /\right.$ year). Waste water use might be employed to mitigate drought stress, but the short and mid-term detrimental effects of salt stress should be quantified. Non-conventional waters are source of nutrients, particularly nitrogen and phosphorous which may potentially modify berry composition and plant's WUE (Bell and Henschke, 2005). Implementing effluent reuse projects results in extra applied loads of nutrients that must be carefully accounted for, due to the potential harmful effects on environment and/or plant performance (Paranychianakis et al., 2006). Together with environmental risks, the risks for human health must be also be studied and demand strict guidance and quality control (MED-EUWI, 2007). The use of recycled water needs to be better studied in viticulture (SARDI, 2009).

\subsection{Canopy and soil management}

It has been shown that warming conditions results in an advance of phenological stages with flowering and veraison occurring earlier with respect to the baseline and in a shorter inter-phase time (Palliotti et al., 2014). There are also situations in which occurs a 
Table 1

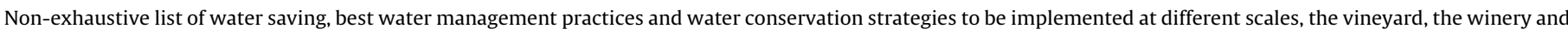
the region.

\begin{tabular}{|c|c|c|c|}
\hline \multirow[t]{2}{*}{ Water saving \& conservation strategies } & \multicolumn{3}{|c|}{ Physical site } \\
\hline & Vineyard & Winery & Region \\
\hline $\begin{array}{l}\text { Install flow meters on wells or at the pump or down individual rows to } \\
\text { estimate water use (in the vineyard and winery); Record data } \\
\text { regularly, set a standard value and search for discrepancies }\end{array}$ & $\mathrm{X}$ & $\mathrm{X}$ & $\mathrm{X}$ \\
\hline $\begin{array}{l}\text { Guarantee maintenance of the irrigation system (filters, flow meters, } \\
\text { gutters, lines) by periodic checking pipe connections and taps for leaks }\end{array}$ & $\mathrm{X}$ & & $\mathrm{X}$ \\
\hline $\begin{array}{l}\text { Deficit irrigation, use well adapted variety/rootstock, proper soil } \\
\text { characterization (profile, water capacity, fertility) }\end{array}$ & $\mathrm{X}$ & & $\mathrm{X}$ \\
\hline $\begin{array}{l}\text { Precise crop/soil monitoring (measure periodically soil and plant } \\
\text { water status (e.g. leaf water potential), measure vineyard's } \\
\text { evapotranspiration) }\end{array}$ & $\mathrm{X}$ & & \\
\hline $\begin{array}{l}\text { Implement "Good Environmental Management Practices" for water, } \\
\text { biocide and fertilizer management, soil management and machinery } \\
\text { and vehicle management }\end{array}$ & $\mathrm{X}$ & & $\mathrm{X}$ \\
\hline $\begin{array}{l}\text { Use pond process water for vineyard and/or landscaping irrigation; } \\
\text { Use drought tolerant species for landscape purposes }\end{array}$ & $\mathrm{X}$ & & $\mathrm{X}$ \\
\hline $\begin{array}{l}\text { Reduce water use in the winery cellar by using water saving } \\
\text { alternatives (e.g. install an ozone system for winery equipment } \\
\text { cleaning/sanitation), monitor water use in washing/soaking of barrels, } \\
\text { install specific flow meter(s) to assess water use in cleaning operations } \\
\text { along the vinification procedures }\end{array}$ & & $\mathrm{X}$ & \\
\hline $\begin{array}{l}\text { Improve waste management and treatment by adapting and } \\
\text { implementing more cost effective treatment technologies for winery } \\
\text { effluents and solid residues }\end{array}$ & & $\mathrm{X}$ & $\mathrm{X}$ \\
\hline $\begin{array}{l}\text { Promote and guarantee staff training (crop management, irrigation } \\
\text { water use, winery cleaning, environmental risk assessment and } \\
\text { general management) }\end{array}$ & $\mathrm{X}$ & $\mathrm{X}$ & $X$ \\
\hline $\begin{array}{l}\text { Optimize technical assistance and support to wine producers to meet } \\
\text { environmental regulations, improve their image near consumers and } \\
\text { their sales }\end{array}$ & $\mathrm{X}$ & $\mathrm{X}$ & $\mathrm{X}$ \\
\hline $\begin{array}{l}\text { Water use benchmarking to set reference values. Develop "water } \\
\text { performance" indicators for both the vineyard and winery, Set targets } \\
\text { and implement auditing, and reporting }\end{array}$ & $\mathrm{X}$ & $\mathrm{X}$ & $\mathrm{X}$ \\
\hline $\begin{array}{l}\text { Quantify market benefits by adopting environmental management } \\
\text { systems and by promoting environmental credentials to guarantee a } \\
\text { good environmental management }\end{array}$ & $\mathrm{X}$ & $\mathrm{X}$ & $\mathrm{X}$ \\
\hline
\end{tabular}

Sources: (Skewes, 1998; COTR-ATEVA, 2009; CWSA, 2011, 2012; CRCV, 2015; Retallack, 2012, 2013; SUSTAVINO, 2012; WATERWIKI, 2015; Radke et al., 2015).

decoupling between anthocyanins and sugars accumulation. Grape ripening is generally accelerated as per increment of sugar accumulation into the berries which in turn can lead to higher alcohol content in the wine if harvest is not anticipated. Moreover, elevated temperatures are also known to induce negative effects on wine colour as a consequence of thermal decoupling of berry anthocyanins and sugars accumulation (Sadras and Moran 2012). There is an increasing number of domestic and foreign consumers preferring wines with moderate alcohol content.

For wine making, significant benefits were described from comprehensive approaches to control shoot vigour through the use of different methods of winter pruning and canopy management such as shoot trimming or thinning (Smart, 1985). Shoot thinning is one of the most widely applied practices in vigorous vineyards to reduce canopy density, optimize sunlight interception, photosynthetic capacity, and fruit microclimate and ultimately improve fruit yield and wine quality. Soil management strategies (tillage vs non-tillage) can also induce changes in the canopy microclimate via indirect effects of water and nutrients competition on vine vegetative growth (Monteiro and Lopes, 2007). The aims of soil surface management in a typical Mediterranean vineyard are multiple encompassing improved weed management and soil conservation, the reduction of soil resource availability to control vine vigour and thus influencing berry composition and in wine quality (Monteiro and Lopes, 2007; Lopes et al., 2011; Guerra and Steenwerth, 2012). In Mediterranean conditions the most widely used soil management practices are soil cultivation in the inter-row combined with herbicides in the row or other control strategies more recommended in biological/organic vineyards. Living green ground covers (grass cover, sown or natural) are also used but not so often because of the concern of excessive water and nutrients competition between the swards and vines (Prichard, 1998; Celette et al., 2008; Lopes et al., 2011, 2015). Indeed when using cover crops in semi-arid areas, favourable effects can be counterbalanced by excessive water competition (Medrano et al., 2014; Lopes et al., 2011) especially if winter and spring periods are dry and/or irrigation water is scarce.

The dual strategies involving soil tillage and the use of cover crops is still matter of debate and solutions are greatly linked to the concept of "terroir" (Pou et al., 2011; Lopes et al., 2014; Medrano et al., 2014). The effects of cover crops on grapevine vigour, yield and berry composition depend on the "terroir", being either (i) beneficial to control vegetative growth and increase berry colour in the case of vigorous genotypes/varieties combined with high spring rainfall or (ii) detrimental, in case of low vigour genotypes/varieties and/or of semi-arid and/or extreme environments because they can result in an excessive reduction in vigour and yield (Pou et al., 2011). Since the impact of the competition between swards and vines changes along the season (Lopes et al., 2008), extended trials are needed (Peterson et al., 2012) to assess the consequences of such type of management approach on vine longevity and in a specific 'terroir'.

\subsection{Selection of rootstocks and varieties resistant to drought and heat}

Among the possible adaptive agronomic measures to use in modern viticulture under the ongoing climate change conditions 
is the selection and cultivation of the best adapted rootstocks and varieties based on differences in temperature requirements for their cultivation (Jones et al., 2005) and WUE characteristics (Costa et al., 2012; Chaves et al., 2010; Tomás et al., 2014a). The right combination of variety/rootstock for a certain environment can determine drought and heat tolerance. Rootstocks influence vigour and drought tolerance via differences in root growth, root hydraulic capacity and also stomatal behaviour (Tandonnet et al., 2010; Cookson and Ollat, 2013; Pavloušek, 2013; Serra et al., 2014). Different rootstocks show varying capacities to extract soil water and transfer it to the scion (Soar et al., 2006), which can be attributed to different efficiency on water transport due to variable xylem vessels anatomy (De Herralde et al., 2006). Different rootstock genotypes show also different root traits (e.g. density and depth); deep and bushy root system permit larger uptake of water and nutrient and a more adequate response to drought and heat stress (Paranychianakis et al., 2006; Koundouras et al., 2008; Pavloušek, 2013; Tramontini et al., 2013). On the other hand, roots have large carbon requirements (e.g. high respiration represents $70-80 \%$ of the total carbon losses (Serra et al., 2014)). Therefore, genotypes with more efficient root systems would be a comparative advantage for dry regions and thinner soils as they would enable a more effective exploitation of soil resources with smaller carbon losses.

\subsection{Precise plant monitoring and phenotyping}

Modern Precision Viticulture involves the use of technologies in which imaging, artificial vision and robotization/automation have a central role and can help to decrease costs and improve input use efficiency such as of water, fertilizers, biocides and energy.

Precision Viticulture is based on technologies that are able to detect spatial heterogeneity of vineyards either due to intrinsic factors (soil and crop management) and/or external variables (climate) and that ultimately will determine inter-annual and intra-vineyard variability with regards to yield and quality output (Mazzeto et al., 2010; Matese et al., 2015; Jones and Grant, 2015). Manual ground-based and aerial manned and unmanned remote sensing measurements are being progressively implemented in modern viticulture not only in research but also in commercial vineyards to monitor plant stress and or to assess canopy and/or berry traits (Costa et al., 2010; Grant et al., 2007; Grant, 2012; Fuentes et al., 2014; Fernández et al., 2013; Jones and Grant, 2015). These new approaches combine the use of different types of detectors and spectral wavelengths ranging from visible (red, green, blue) (RGB) and infrared thermal imaging to multispectral and tomography measurements (Leionen et al., 2006; Diago et al., 2012; Fuentes et al., 2012; Costa et al., 2013; Jones and Grant, 2015; Rustioni et al., 2014). Robots and unmanned Aerial Vehicles (UAVs) have been recently applied in precision viticulture (Baluja et al., 2012; ZarcoTejada et al., 2009, 2012; Gago et al., 2015). UAVs offer advantages relatively to ground based measurements. UAVs have high flexibility of use, low operational costs and a very high spatial resolution, that can be down to $1 \mathrm{~cm}$ (Matese et al., 2015; Gago et al., 2015). However, the legislation regulating their use in certain EU countries demands still clarification for a broader use in agriculture (Costa et al., 2013). Satellite imaging has also been used in grapevine studies namely to assess water stress (Consoli and Barbagallo, 2012) and intra-variability in vigour and leaf expansion (Matese et al., 2015; Jones and Grant, 2015)

Soil monitoring is another relevant aspect of remote sensing. Assessment of soil water in field conditions must be accurate especially over large and heterogeneous surfaces. Electrical Resistivity Tomography meets these requirements for applications in plant sciences, agriculture and ecology (Brillante et al., 2014). Also the combined use of aerial and ground based thermal imaging permits to monitor soil water in vineyards (Soliman et al., 2013).
These authors found that spatial patterns of soil moisture correlated better with thermal inertia data than with measured surface temperature and suggested to use it as a potential indicator for vineyard irrigation management. Optimizing the use of thermal and vegetation indexes as means to gather more robust information on crop water stress is another important component of crop monitoring based on thermography.

Regarding plant phenotyping, since grapevine is a perennial field crop, acquisition of phenotypic data is almost restricted to the field and is usually carried out by visual estimation. This is time consuming and can be affected by subjectivity. Consequently, fully and/or partially automated phenotyping is needed to increase the number of samples monitored to manage grapevine repositories, to enable genetic research of novel phenotypic characteristics and ultimately to increase efficiency in grapevine phenotypying and breeding (Kicherer et al., 2015). Moreover, the available high-throughput phenotyping platforms can contribute to improve grapevine phenotyping and breeding (Kicherer et al., 2015). Phenotyping canopy traits can be simpler to perform by imaging than fruits and roots. Recent results in grapevine showed that visible RGB images permit to assess bunch compactness (Cubero et al., 2015) and a high-throughput image interpretation tool to acquire the number, diameter and volume of grapevine berries (Berry Analysis Tool-BAT) has been recently developed (Kicherer et al., 2013). Finally, cheaper and more user friendly technologies for crop monitoring and phenotyping are on demand. As an example, Fuentes et al. (2014) have recently proposed an inexpensive but robust automated computational method to obtain leaf area index and canopy vigour parameters from grapevines based on RGB imaging and video analysis with MATLAB.

\section{Sustainable water use}

\subsection{Sustainability standards and water use indicators}

The wine industry, just like any other intensive agribusiness activity or sector's of industry has an environmental impact that must be obligatorily taken into account for consideration. Although wine production is one of the most innovative and competitive industries at global scale, the environmental issues remain overall poorly perceived (Barber et al., 2009; Marshall et al., 2005; Christ and Burritt, 2013). Therefore a more objective quantification of its environmental impact is crucial particularly in terms of water use. Water performance metrics involves a precise quantification of water inputs and outputs in the vineyard and winery making it easier to assess their environmental and economical performance (CWSA, 2011). Performance metrics also contributes to predict future water needs and expenses which is particularly relevant under unfavourable scenarios (stressful environments, water scarcity) and stricter environmental rules (CWSA, 2011). Unfortunately, numerous indexes available to classify "sustainability" of the wine sector shows that there are differences among countries which makes it more difficult to classify companies because of the differences in index composition and in the trait of sustainability under observation (Santini et al., 2013). In California, the use of metrics permitted the use of natural resources (water, energy) and helped to optimize vineyard operations, reduce costs and increase sustainability (CWSA, 2011). In New Zealand, vineyards and wineries can report water use per vineyard and per winery annually to the Sustainable Winegrowing New Zealand and this information will be used to establish benchmarks for members (www. nzwine.com). Australia in turn has been promoting for a long time, water use benchmarking of vineyards (Skewes, 1998; Walker and Boland 2004) and in Portugal, the same approach was was carried out for Alentejo's wine region (COTR-ATEVA, 2009). Skewes (1998) 
suggests a set of potential indicators for water use such as: (1) Yield (ton/ha); (2) Crop WUE (ton/water use); (3) Return per water applied; (4) Cost of water per tonne of fruit; (5) Irrigation efficiency; (6) Yield per volume of drainage (Ton/ $\mathrm{m}^{3}$ of water) or (7) Cost of drainage per tonne of fruit (Euros/ton). In addition, the relationship of these water use indicators with major berry/wine quality attributes (e.g. sugar content, colour, flavour and aroma components) should be also considered in future audits. Benchmarking approaches would help to improve efficiency by setting a standard and a reference. However, we may have also to consider that some small farms and businesses are not willing to present their own results nor being evaluated by their counterparts. The use of more objective parameters and performance metrics are also needed for South European Mediterranean regions such as in Portugal and Spain.

\subsection{Water foot print (WFP) and Life cycle analysis (LCA)}

The strong and growing trend towards industry certification in terms of environmental sustainability is being translated into concepts such as ecological footprint (Hoekstra et al., 2011; Ene et al., 2013; Lamastra et al., 2014). The concept of water footprint (WFP) emerged as a basic, theoretical, consumption-based indicator of water use and looks at both direct and indirect water use by a consumer or producer (Hoekstra et al., 2011). It is calculated by the volume of fresh water used to produce the product, measured over the various steps of the production chain (Hoekstra et al., 2011). For food crops, the WFP concept includes all the fresh water consumed per unit of product (e.g. per litre of wine), namely to grow the crop, the water used in post-harvest processing and also the polluted water produced (volume of freshwater required to assimilate the pollutants load). The WFP is being used to indicate the impacts of water use by production systems and there have been an increasing number of governments/companies recognising that reducing WFP is part of the country/corporation environmental strategy (Hoekstra and Mekonen, 2012; Herath et al., 2013).

An important recent development is the fact that the International Organization for Standardization (ISO) developed the International Standard ISO 14046, "Environmental management-Water footprint-Principles, requirements and guidelines", which aims at providing decision makers in industry, government and non-governmental organizations with the means to estimate the potential impact of water use and pollution, based on a lifecycle assessment (http://www.iso.org/iso/iso14046_briefing_note. pdf). This has enlarged the set of indicators related to environment sustainability and water use and protection that ISO makes available for the industry.

However, there are some authors arguing on the effectiveness of WFP as neither WFP is as accurate as a hydrological based approach nor a helpful indicator of water use and water management in agriculture (Perry, 2014). Therefore, the classical WFP requires more refinement for food groups, especially in the case of grapes and wine. In fact WFP should incorporate large regional/temporal variation for agricultural products due to the variable environmental context (Hoekstra et al., 2011; Maes et al., 2009; Berger and Finkbeiner, 2011; Vanham and Bidoglio, 2013), different agronomic strategies (e.g. irrigation vs non irrigated) or different growth and water use performance of genotypes which generates variation in evapotranspiration. This seems not to be sufficiently accounted in the classical calculations of WFP. Moreover, generalized values for WFP for a certain commodity can hide differences between regions and may mislead consumers and authorities (Maes et al., 2009; Perry, 2014). In addition, the classic WFP estimation has also limitations in the assessment of relevant water issues such as water quality and water pollution.
Together with the WFP, the Life Cycle Assessment (LCA) methodology provides a possible framework to evaluate environmental impacts of products and production systems across their entire lifespan and can be applied to durable, disposable or edible goods including food products (Notarnicola et al., 2012; Gazulla et al., 2010; Arzoumanidis et al., 2013, 2014; Torrellas et al., 2013). The LCA is a standardized method which is in accordance to the ISO rules (ISO 14040:2006 and ISO14044:2006) (ISO, 2006; Barjoveanu et al., 2010; Finnveden et al., 2009; Teodosiu et al., 2012).

There are still few literature studies on the environmental effects of wine production on a complete lifecycle perspective (Gazulla et al., 2010; Benedetto 2013). These studies have shown that the major bottlenecks and environmental impacts in wine production refer to the viticulture phase and also to glass production for bottles. In fact, the largest percentage of water use in the wine supply chain relates to the cultivation phase whereas a minor percentage resides in the vinification and production of packaging materials (Ene et al., 2013). To guarantee a wider use of LCA information, there is a need to simplify LCA methodology and determination (Torrellas et al., 2013). This is especially true if we consider the characteristics of the wine sector in the Mediterranean characterised by a large number of small- and medium-sized Enterprises (SMEs) with limited knowledge or resources to implement the conventional full LCAs (Arzoumanidis et al., 2014). A simplified LCA tool is now available online, the eVerdEE tool (http://www.ecosmes. net/everdee/login2 (accessed on 10 July 2014)) that allows its users to directly fill it in and obtain results with regard to the environmental performance of a product. This tool can be accessed for free, after registration (Arzoumanidis et al., 2014).

\subsection{Legislation and statistics for sustainable water use}

Legislation and statistics on water use and management is essential to guarantee the optimal use of scarce resources. Five major categories of tools can help to implement and guarantee a proper management of water at regional and national levels: regulatory, enforcement, economic, participative and integrated (Medellín-Azuara et al., 2013) (See Table 2). In the case of $\mathrm{EU}$, the main policy objectives in relation to water use and water stress were set out in the 6th Environment Action Programme (EAP) (1600/2002/EC) and the Water Framework Directive (WFD,2000/60/EC) whose major aim is to ensure the sustainable use of water resources. The more recent policy document is the 'Blueprint to safeguard Europe's water resources' (COM/2012/0673) which aims at ensuring that good quality water of sufficient quantity, is available for all legitimate uses (EUROSTAT, 2015). The "Blueprint" is a new strategy to reinforce water management in the EU and is closely related to the Europe 2020 strategy, in particular, to the roadmap for resource efficiency (EU Commission, 2014a,b; EUROSTAT, 2015). Concerning this topic, the EU Commission had already issued in 2007 a Communication on Water Scarcity and Droughts, establishing five pillars: (1) put right price tag on water, (2) promote more efficient water related technologies and practices, (3) improve drought risk management, (4) enhancing a water-saving culture and (5) improve knowledge and statistical data collection (EEA, 2012a,b). However, EU's architecture can be problematic for down-scaling water policies to national, regional and local levels, resulting in not common objectives among different EU members (Villarejo and Lopez, 2014). In Portugal, an implementation program for legislation on water issues has been implemented ("Plano Português para Uso Eficiente de Água") and Spain, in turn, put in place the so called "Plan Nacional del Agua".

Accurate statistics and estimation of water use and irrigation demands is a key requirement for precise water management (Maton et al., 2005) and a large scale overview on European water use can contribute to developing more correct water management 
Table 2

Indicative list of resources and policy tools to govern water management and water conservation.

\begin{tabular}{l} 
Resources and measu \\
\hline Water statistics
\end{tabular}

Regulatory measures

Enforcement measures

Economic measures

Participative and integrative measures

Description of the tools

- Water statistics are crucial to report obligations to international organizations (UNSD/UNEP,

Eurostat/OECD) and to support EU

and national management of environmental and

socio-economic conditions for a more sustainable development

- Robust water statistics will

support a more correct use and

implementation of different

measures (regulatory,

enforcement, economic,

participative)

- Contains the instruments to conserve overexploited

basins/aquifers by implementing

prohibitions, reserves and regulations

- Involves enforcement regulations to control and manage the use of water and water discharge

- Implementation based on field inspections, quality monitoring. auditing, sanctions for misconduct

- Use economic instruments (incentives) to implement novel water policies and regulations following the principle of "water user pays" and "polluter pays"

- Use incentives that may include lower taxes for growers/wineries showing higher water use efficiency and more sustainable practices. The use of incentives to promote efficiency should be considered by both regional and central governments

- Water pricing/charges applied on a volumetric basis

- It is a policy tool to promote community participation in planning, policy development and water management. It involves participation of water user associations, technical committees for water resources,

representatives of different sectors (e.g. tourism, agribusiness, national and regional water management authorities)

- Involves awareness-raising by stakeholders and dissemination of information/statistics concerning water.

Sources: (EEA, 2012a,b; EU Commission, 2014a,b; D’Amore, 2005; Medellin-Azuara et al., 2013; Radke et al., 2015).

policies and strategies. However, there is still a significant lack of water related statistical information for policy decision on aspects such as aquifer recharge, water abstraction by farmers, irrigation pollution emissions from either surface or subsurface water, soils (Albiac et al., 2005; EEA, 2012a,b; Ferreira et al., 2015). In fact, Portugal lacks up-to-date statistics related to water and there is large discontinuity of data related to water uses and water masses (Ferreira et al., 2015). Unfortunately, the problem of scarcity, non homogeneous and disaggregated statistical data seems to be experienced by other Southern European countries as well (Albiac et al., 2005; EEA 2012a,b).

\section{Consumer perspectives and marketing}

Consumer awareness of sustainable winegrowing and winemaking remains low and the concepts such as "sustainable product" or "sustainable processes" are confounded with vague terms e.g. "organic" and "green" (Zucca et al., 2009). However, the perception on the assessment of environmental and economic sustainability of wine's supply chain by stakeholders is increasing and becoming a concern for growers, entrepreneurs, consumers and public decision makers (Point et al., 2012; Strano et al., 2013; Dawson et al., 2011; Fountain and Tompkins, 2011; Pullman et al., 2010; Radke et al., 2015). The wine industry should develop appropriate marketing strategies to help consumers to identify and distinguish between sustainable and non sustainable products (Zuca et al., 2009) and avoid any type of marketing practices that may mislead consumers about firm environmental performance or benefits of a certain product or service (so called "greenwashing") (Delmas and Cuerel Burbano, 2011). This has the negative effect on consumers and investors' confidence in environmentally friendly firms and products (Delmas and Cuerel Burbano, 2011) and jeopardizes efforts of stakeholders to build up a true and effective sustainability concept. In a recent transnational study, wineries have also complained about the lack of information existing among relevant organizations, producers and consumers in terms of environmental sustainability (Szolnoki, 2013). This requires increased cooperation between organizations/associations to optimize the flow of information in the wine supply chain (Christ and Burritt, 2013; Broome and Warner 2008; Santini et al., 2013).

\section{Final considerations}

Future scenarios for the Mediterranean viticulture encompasses approaches at different levels (from plant physiology to consumer behaviour) to guarantee a more economically and environmentally sustainable wine production. The sustainable use of water is of outmost importance and must be guaranteed at the vineyard, winery and regional levels. Therefore, future strategies to optimize the environmental performance of the wine sector in the Mediterranean must be focused on water. This starts in the breeding for improved plant adaptation to heat and drought stress and ends in strategies to save water in the vinery and winery. Robust water use statistics at both EU and national levels are needed. Also the correct use of indicators (WFP, LCA, ISO norms) coupled to effective water policies will help make the Mediterranean wine industry more efficient in terms of water use minimizing its environmental impact.

Improved crop performance under more stressful conditions of water by controlling grapevine water relations and canopy temperature should take place in parallel with optimized deficit irrigation and water reuse. Soil maintenance influencing soil and plant water relations as well as soil fertility and temperature will have impact on plant performance and berry quality. Nowadays, a large set of technologies is available for ground and aerial sensing but novel technologies must be better integrated and properly validated for different genotypes and for different strategies of plant and soil management. Low cost but effective remote sensing technologies would help to generalise their use by an increasing number of small companies and growers.

Water statistics and improved performance metrics at the vineyard and winery are required to optimize water use along the supply chain. Proper audit programs to water use should be promoted by authorities, association or organizations related to wine supply chain. Consumer perception on wine industry impact on the environment tends to increase and requires novel approaches to operate in the wine supply chain. New concepts have been 
emerging in the modern viticulture namely the ecological footprint (water, carbon, social) and "vinecology", which emphasises the need to integrate ecological and viticultural practices to guarantee nature conservation, landscape protection and diversity (Viers et al., 2013). In addition, wine tourism is now an important complement of wine production worldwide (Barber et al., 2009, 2010) including Portugal and Spain (Radke et al., 2015; Gómez and Molina, 2011). Landscape scenery and the environmental attractiveness have become major components of the wine tourism and must be also protected (Bruwer and Alant, 2009; Leddy, 2013; Dawson et al., 2011; Fountain and Tompkins, 2011). Therefore, tourism can be an extra trigger for farme and winery managers to implement best management practices in the vineyard and winery, and ultimately contribute to minimize the environmental impact of the wine industry.

\section{Uncited references}

Birch et al. (2011), Costantini and Barbetti (2008), Eibach and Töpfer (2015), Fernández et al. (2014), Fusi et al. (2014), Lopes et al. (2004), Ruggieri et al. (2009), and Torres-Ruiz et al. (2014).

\section{Acknowledgements}

This research received funding from European Community's Seventh Framework Programme (FP7/2007-2013) under the grant agreement no. FP7-311775, Project INNOVINE. J. Miguel Costa and $\mathrm{R}$, Egipto had a scholarship from INNOVINE. JM Costa was also funded by FCT (SFRH/BPD/93334/2013), Portugal. We also thank the support from the Research unit GREEN-it "Bioresources for Sustainability"(UID/Multi/04551/2013). This work was also performed with financial support from the Spanish Ministry of Science and Technology (project AGL 2014-54201-C4-1R).

\section{$900 \quad$ References}

Albiac, J., Martinez, Y., Tapia, J., 2005. Water quantity and quality issues in Mediterranean Agriculture. In: OECD Workshop on Agriculture and Water: Sustainability, Markets and Policies, Adelaide, Australia, 14-18 November 2005 http://www.oecd.org/agr/env

Alsina, M.M., Smart, D.R., Bauerle, T., de Herralde, Felicidad., Biel, C., Stockert, C., Negron, C., Save, R., 2011. Seasonal changes of whole root system conductance by a drought-tolerant grape root system. J. Exp Bot. 62, 99-109.

Angelakis, A.N., Gikas, P., 2014. Water reuse: overview of current practices and trends in the world with emphasis on EU states. Water Utility J. 8, 67-78.

Arzoumanidis, I., Petti, L., Raggi, A., Zamagni, A., 2013. The implementation of simplified LCA in agri-food SMEs. In: Product-oriented Environmental Management Systems (POEMS). Springer, Netherlands, pp. 151-173.

Arzoumanidis, I., Raggi, A., Petti, L., 2014. Considerations when applying simplified LCA approaches in the wine sector. Sustainability 6 (8), 5018-5028.

Baluja, J., Diago, M.P., Balda, P., Zorer, R., Meggio, F., Morales, F., Tardaguila, J., 2012. Assessment of vineyard water status variability by thermal and multispectral imagery using an unmanned aerial vehicle (UAV). Irrig. Sci. 30 (6), 511-522.

Barber, N., Taylor, C., Strick, S., 2009. Wine consumers' environmental knowledge and attitudes: Influence on willingness to purchase. Int. J. Wine Res. 1, 59-72.

Barber, N., Taylor, D.C., Deale, C.S., 2010. Wine tourism, environmental concerns, and purchase intention. J. Travel Tour. Mark 27, 146-165.

Barisan, L., Boatto, V., Costantini, E.A.C., Galletto, L., Lorenzetti, R., Pomarici, E. Vecchio, R., 2014. A sustainable response to the requirements of the aware consumer: the case of the new drought-resistant rootstocks. Proceedings 8th International Conference of the Academy of Wine Business (AWBR), p. 15.

Barjoveanu, G., Comandaru, I.M., Teodosiu, C., 2010. Life cycle assessment of water and wastewater treatment systems: an overview. Bull. Politechnic Inst. Iasi 56, $73-86$

Baudron, P., Barbecot, F., Aróstegui, J.L.G., Leduc, C., Travi, Y., Martinez-Vicente, D. 2014. Impacts of human activities on recharge in a multilayered semiarid aquifer (Campo de Cartagena, SE Spain). Hydrol. Process. 28 (4), 2223-2236.

Bell, S.J., Henschke, P.A., 2005. Implications of nitrogen nutrition for grapes, fermentation and wine. Aust. J. Grape Wine Res. 11, 242-295.

Benedetto, G., 2013. The environmental impact of a Sardinian wine by partial life cycle assessment. Wine Econ. Policy 2 (1), 33-41.

Berger, M., Finkbeiner, M., 2011. Correlation analysis of life cycle impact assessment indicators measuring resource use. Int. J. Life Cycle Assess 16 (1), $74-81$
Berghoef, N., Dodds, R., 2011. Potential for sustainability eco-labeling in Ontario's wine industry. Int. J. Wine Bus. Res. 23 (4), 298-317.

Bergqvist, J., Dokoozlian, N., Ebisuda, N., 2001. Sunlight exposure and temperature effects on berry growth and composition of Cabernet Sauvignon and Grenache in the Central San Joaquin Valley of California. Am. J. Enol. Vitic. 52 (1), 1-7.

Birch, A.N.E., Begg, G.S., Squire, G.R., 2011. How agro-ecological research helps to address food security issues under new IPM and pesticide reduction policies for global crop production systems. J. Exp. Bot. 62 (10), 3251-3261.

Blum, W., 2014. Land degradation and security linkages in the Mediterranean region. In: Kapur, B.S., Ersahin, S. (Eds.), Soil Security for Ecosystem Management, 8. Springer Briefs in Environment, Security, Development and Peace, pp. 19-29.

Bondada, B., Shutthanandan, J., 2012. Understanding differential responses of grapevine (Vitis vinifera L.) leaf and fruit to water stress and recovery following re-watering. Am. J. Plant Sci. 3, 1232-1240.

Bota, J., Flexas, J., Medrano, H., 2001. Genetic variability of photosynthesis and water use in Balearic grapevine cultivars. Ann. Appl. Biol. 138 (3), 353-361.

Brillante, L., Mathieu, O., Bois, B., van Leeuwen, C., Lévêque, J., 2014. The use of soil electrical resistivity to monitor plant and soil water relationships in vineyards. Soil Disc 1 (1), 677-707

Broome, J.C., Warner, K.D., 2008. Agro-environmental partnerships facilitate sustainable wine-grape production and assessment. California Agric. 62 (4).

Bruwer, J., Alant, K., 2009. The hedonic nature of wine tourism consumption: an experiential view. Int. J Wine Bus. Res. 21 (3), 235-257.

Carreira, P.M., Marques, J.M., Nunes, D., 2014. Source of groundwater salinity in coastline aquifers based on environmental isotopes (Portugal): natural vs. human interference. A review and reinterpretation. Appl. Geochem. 41, $163-175$.

Carvalho, L.C., Vidigal, P., Amâncio, S., 2015. Oxidative stress homeostasis in grapevine (Vitis vinifera L.). Front. Environ. Sci. 3, 20.

Chaves, M.M., Zarrouk, O., Francisco Costa, J.M., Santos, T., Regalado, A.P. Rodrigues, M.L., Lopes, C.M., 2010. Grapevine under deficit irrigation-hints from physiological and molecular data. Ann. Bot. 105, 661-676.

Chaves, M.M., Santos, T.P., Souza, C.R., Ortuno, M.F., Rodrigues, M.L., Lopes, C.M., Maroco, J.P., Pereira, J.S., 2007. Deficit irrigation in grapevine improves water-use efficiency while controlling vigour and production quality. Ann Appl. Biol. 150 (2), 237-252.

Christ, K.L., Burritt, R.L., 2013. Critical environmental concerns in wine production: an integrative review. J. Cleaner Prod. 53, 232-242.

Celette, F., Gaudin, R., Gary, C., 2008. Spatial and temporal changes to the water regime of a Mediterranean vineyard due to the adoption of cover cropping. Eur. J. Agron. 29, 153-162.

Consoli, S., Barbagallo, S., 2012. Estimating water requirements of an irrigated mediterranean vineyard using a satellite-based approach. J. Irrig. Drain Eng. 138 (10), 896-904.

Cookson, S.J., Ollat, N., 2013. Grafting with rootstocks induces extensive transcriptional re-programming in the shoot apical meristem of grapevine. BMC Plant Biol. 2, 13-147.

Conde, A., Regalado, A., Rodrigues, D., Costa, J.M., Blumwald, E., Chaves, M.M. Gerós, H., 2015. Polyols in grape berry: transport and metabolic adjustments as a physiological strategy for water-deficit stress tolerance in grapevine. J. Exp. Bot. 66 (3), 889-906.

Condon, A.G., Richards, R.A., Rebetzke, G.J., Farquhar, G.D., 2004. Breeding for high water-use efficiency. J. Exp. Bot. 55 (407), 2447-2460.

Condon, A.G., Richards, R.A., Rebetzke, G.J., Farquhar, G.D., 2002. Improving intrinsic water-use efficiency and crop yield. Crop Sci. 42 (1), 122-131.

Costa, J.M., Ortuño, M.F., Chaves, M.M., 2007. Deficit irrigation as a strategy to save water: physiology and potential application to horticulture. J. Int. Plant Biol. 49 (10), 1421-1434.

Costa, J.M., Grant, O.M., Chaves, M.M., 2010. Use of thermal imaging in viticulture: current application and future prospects. In: Delrot, S., Medrano, H., Or, E., Bavaresco, L., Grando, S. (Eds.), Methodologies and Results in Grapevine Research. Springer, Dordrecht, Netherlands, pp. 135-150.

Costa, J.M., Ortuño, M.F., Lopes, C.M., Chaves, M.M., 2012. Grapevine varieties exhibiting differences in stomatal response to water deficit. Funct. Plant Biol. 3 , 179-189.

Costa, J.M., Grant, O.M., Chaves, M.M., 2013. Thermography to explore plant-environment interactions. J. Exp. Bot. 64 (13), 3937-3949.

Costa, J.M., Reis, M., Passarinho, J.A., Palha, M.G., Carvalho, S.M.P., Ferreira, M.E. 2014. Sustentabilidade sócio-ambiental da horticultura protegida em Portugal. In: VII Congreso Ibérico de Agroingenieria y Ciencias Hortícolas: Innovar y Producir para el Futuro (F.G. UPM, ed), Madrid, pp. 1805-1810.

Costantini, E.A., Barbetti, R., 2008. Environmental and visual impact analysis of viticulture and olive tree cultivation in the province of Siena (Italy). Eur. J. Agron. 28 (3), 412-426.

COTR-ATEVA, 2009. Benchmarking na rega e boas práticas na gestão da rega da vinha. Eds. Centro Operativo e de Tecnologia do Regadio, Associação Técnica dos Viticultores do Alentejo, http://www.ateva.pt/site_media/cms_page_media 58/Boas\%20Praticas\%20de\%20gest\%C3\%A30\%20da\%20Rega\%20da\%20Vinha.pdf.

Coupel-Ledru, A., Lebon É, Christophe, A., Doligez, A., Cabrera-Bosquet, L., Péchier, P., Simonneau, T., 2014. Genetic variation in a grapevine progeny (Vitis vinifera L. cvs GrenacheÉ Syrah) reveals inconsistencies between maintenance of daytime leaf water potential and response of transpiration rate under drought. J. Exp. Bot. 65, 6205-6218. 
Cubero, S., Diago, M.P., Blasco, J., Tardaguila, J., Prats-Montalbán, J.M., Ibáñez, J., Tello, J., Aleixos, N., 2015. A new method for assessment of bunch compactness using automated image analysis. Aust. J. Grape Wine Res. 21, 101-109.

CRCV, 2015. Cooperative Research Centre for Viticulture, http://www.crcv.com.au/ resources/environment/Additional\%20Resources/ Good\%20Environmental\%20Management\%20in\%20Viticulture\%202005.pdf WSA, 2011. Introduce Performance Metrics for Sustainable wine growing Data to Determine Industry Averages for Water, Energy and Nitrogen Use. California Sustainable Winegrowing Aliance, https://www.wineinstitute.org/files/CSWA Performance_Metrics_Winter_2011-12.pdf

CWSA, 2012. Performance Metrics and the California Sustainable Winegrowing Program. California Sustainable Winegrowing Aliance, https://metrics. sustainablewinegrowing.org/docs/ Performance\%20Metrics\%20and\%20the\%20SWP_Final_3.15.12.pdf

D'Amore, G., 2005. An integrated approach for water statistics. IWG-Env. In: International Work Session on Water Statistics, Vienna, June 20-22 http:// unstats.un.org/unsd/environment/envpdf/pap_wasess4a5icstat.pdf

Dawson, H., Holmes, M., Jacobs, H., Wade, R.I., 2011. Wine tourism: winery visitation in the wine appellations of Ontario. J. Vacation Market 17 (3), 237-246.

De Leo, F., Miglietta, P.P., Massari, S., 2015. Water sustainability assessment of Italian vineyards doc vs generic wines. Proceedings Specialized conference of the EuroMed Academy of Business. Contemporary Trends and Perspectives in Wine and Agrifood Management, 133-145.

De Herralde, F., del Mar Alsina, M., Aranda, X., Savé, R., Beil, C., 2006. Effects of rootstock and irrigation regime on hydraulic architecture of Vitis vinifera L. cv Tempranillo. Int. J. Sci. Wine Vine 40, 133-139.

Delmas, M.A., Cuerel Burbano, V., 2011. The drivers of greenwashing. Calif. Manage. Rev. http://ssrn.com/abstract=1966721

Diago, M.P., Correa, C., Millán, B., Barreiro, P., Valero, C., Tardaguila, J., 2012. Grapevine yield and leaf area estimation using supervised classification methodology on RGB images taken under field conditions. Sensors 12 (12), 16988-17006.

Dodd, I.C., 2009. Rhizosphere manipulations to maximize 'crop per drop'during deficit irrigation. J. Exp. Bot. 60 (9), 2454-2459.

EASAC, 2013. Trends in extreme weather events in Europe: implications for national and European Union adaptation strategies. European Academies Science Advisory Council policy report 22. November 2013, ISBN: 978-3-8047-3239-1, http://www.easac.eu/fileadmin/PDF_s/reports statements/Easac_Report_Extreme_Weather_Events.pdf.

ECOPROWINE, 2014. http://www.ecoprowine.eu/home/.

EEA, 2012a. Towards efficient use of water resources in Europe. European Environment Agency Report No 1/2012, http://www.eea.europa.eu/ publications/towards-efficient-use-of-water.

EEA, 2012b. Vulnerability to water scarcity and drought in Europe. European Environment Agency, http://icm.eionet.europa.eu/ETC_Reports/ VulnerabilityToWaterScarcityAndDroughtInEurope/WSD_Vulnerability Report_for_publication_final_20121220.pdf

Eibach, R., Töpfer, R., 2015. Traditional grapevine breeding techniques. In: Andrew Reynolds, G. (Ed.), Grapevine Breeding Programs for the Wine Industry: Traditional and Molecular Techniques. Woodhead Publishing Series in Food Science, Technology and Nutrition. Elsevier, UK, pp. 4-22.

Ene, S.A., Teodosiu, C., Robu, B., Volf, I., 2013. Water footprint assessment in the winemaking industry: a case study for a Romanian medium size production plant. J. Cleaner Prod 43, 122-135.

ERANETMED, 2014. http://www.eranetmed.eu/.

EU Comission, 2014a. http://ec.europa.eu/environment/water/quantity/pdf/BIO Water\%20savings\%20in\%20agiculture_Final\%20report.pdf.

EU Comission, 2014b. http://ec.europa.eu/environment/water/quantity/pdf/ agriculture_report_ANNEXES.pdf.

EUROSTAT, 2015. http://ec.europa.eu/eurostat/statistics-explained/index.php/ Water_statistics.

FAO, 2013. Good Agricultural Practices for Greenhouse Vegetable Crops. Principles for Mediterranean Climate Areas. Food and Agriculture Organization of the UN, Rome.

Fernández, R., Montes, H., Salinas, C., Sarria, J., Armada, M., 2013. Combination of RGB and multispectral imagery for discrimination of cabernet sauvignon grapevine elements. Sensors 13 (6), 7838-7859.

Fernández, R., Salinas, C., Montes, H., Sarria, J., 2014. Multisensory system for fruit harvesting robots. experimental testing in natural scenarios and with different kinds of crops. Sensors 14 (12), 23885-23904.

Ferreira, J.G., Schmidt, L., Guerra, J., 2015. Índice de Transparência na Gestão da Água em Portugal (Intrag) Livro de Atas do 1. o. Congresso da Associação Internacional das Ciências Sociais e Humanas em Língua Portuguesa, 7058-7072.

Finnveden, G., Hauschild, M.Z., Ekvall, T., Guinée, J., Heijungs, R., Hellweg, S., Suh, S., 2009. Recent developments in life cycle assessment. J. Environ. Manag. 91 (1), 1-21.

Flexas, J., Ribas-Carbó, M., Bota, J., Galmés, J., Henkle, M., Martínez-Cañellas, S. Medrano, H., 2006. Decreased Rubisco activity during water stress is not induced by decreased relative water content but related to conditions of low stomatal conductance and chloroplast $\mathrm{CO}_{2}$ concentration. New Phytol. 172 (1), 73-82.

Flexas, J., Barón, M., Bota, J., Ducruet, J.M., Galle, A., Galmes, J., Jimenez, M., Pou, A., Ribas-Carbo, M., Sajnani, C., Tomas, M., Medrano, H., 2009. Photosynthesis limitations during water stress acclimation and recovery in the drought-adapted Vitis hybrid richter-110 (V. berlandieri $\times$ V. rupestris). J. Exp Bot. $60(8), 2361-2377$.

Flexas, J., Scoffoni, C., Gago, J., Sack, L., 2013. Leaf mesophyll conductance and leaf hydraulic conductance: an introduction to their measurement and coordination. J. Exp. Bot. 64 (13), 3965-3981.

Forbes, S.L., Cohen, D.A., Cullen, R., Wratten, S.D., Fountain, J., 2009. Consumer attitudes regarding environmentally sustainable wine: an exploratory study of the New Zealand marketplace. J. Cleaner Prod. 17, 1195-1199.

Fountain, J., Tompkins, J.M., 2011. The potential of wine tourism experiences to impart knowledge of sustainable practices: the case of the Greening Waipara biodiversity trails. In: Proceedings of the 6th AWBR InternationalConference, 9-10 June 2011, Bordeaux Management School, BEM, France, p. 17.

Fraga, H., Malheiro, A.C., Moutinho-Pereira, J., Santos, J.A., 2013. Future scenarios for viticultural zoning in Europe: ensemble projections and uncertainties. Int. J. Biometeorol. 57 (6), 909-925.

Fraga, H., Santos, J.A., Malheiro, A.C., Oliveira, A.A., Moutinho-Pereira, J., Jonesb, G.V., 2015. Climatic suitability of Portuguese grapevine varieties and climate change adaptation. Int. J. Climatol., http://dx.doi.org/10.1002/joc.4325.

Fuentes, S., De Bei, R., Pech, J., Tyerman, S., 2012. Computational water stress indices obtained from thermal image analysis of grapevine canopies. Irrig. Sci. 30 (6), 523-536.

Fuentes, S., Poblete-Echeverría, C., Ortega-Farias, S., Tyerman, S., De Bei, R., 2014. Automated estimation of leaf area index from grapevine canopies using cove photography, video and computational analysis methods. Aust. J. Grape Wine Res. 20, 465-473.

Fusi, A., Guidetti, R., Benedetto, G., 2014. Delving into the environmental aspect of a Sardinian white wine: from partial to total life cycle assessment. Sci. Total Environ. 472, 989-1000.

Gago, J., Douthe, C., Coopman, R.E., Gallego, P.P., Ribas-Carbo, M., Flexas, J., Escalona, J.M., Medrano, H., 2015. UAVs challenge to assess water stress for sustainable agriculture. Agric. Water Manag. 153, 9-19.

Gambetta, G.A., Fei, J., Rost, T.L., Knipfer, T., Matthews, M.A., Shackel, K.A. McElrone, A.J., 2013. Water uptake along the length of grapevine fine roots: developmental anatomy, tissue-specific aquaporin expression, and pathways of water transport. Plant Physiol. 163 (3), 1254-1265.

Gaudillère, J.P., Van Leeuwen, C., Ollat, N., 2002. Carbon isotope composition of sugars in grapevine, an integrated indicator of vineyard water status. J. Exp. Bot. 53 (369), 757-763.

Gazulla, C., Raugei, M., Fullana-i-Palmer, P., 2010. Taking a life cycle look at crianza wine production in Spain: where are the bottlenecks? Int. J. Life Cycle Assess. 15 (4), 330-337.

Gerling, C., 2015. In: Gerling, C. (Ed.), Environmentally Sustainable Viticulture: Practices and Practicality. Apple Academic Press, Inc., Canada.

Goderniaux, P., Brouyère, S., Fowler, H.J., Blenkinsop, S., Therrien, R., Orban, P., Dassargues, A., 2009. Large scale surface-subsurface hydrological model to assess climate change impacts on groundwater reserves. J. Hydrol. 373 (1), $122-138$.

Gökbayrak, Z., Soylemezoglu, G., Akkurt, M., Celik, H., 2007. Determination of grafting compatibility of grapevine with electrophoretic methods. Sci. Hort $113,343-352$.

Gómez-del-Campo, M., Baeza, P., Ruiz, C., Sotés, V., Lissarrague, J.R., 2007. Effect of previous water conditions on vine response to rewatering. Vitis 46, 51-55.

Gómez, M., Molina, A., 2011. Wine tourism in Spain: denomination of origin effects on brand equity. Int. J. Tour. Res. 14 (4), 353-368.

Gonçalves, E., Martins, A., 2015. Genetic Variability Evaluation and Selection in Ancient Grapevine Varieties. http://cdn.intechopen.com/pdfs-wm/25564.pdf

Grant, O.M., 2012. Thermography in viticulture. Thermol. Int. 22, 16-24.

Grant, O.M., Tronina, L., Jones, H.G., Chaves, M.M., 2007. Exploring thermal imaging variables for the detection of stress responses in grapevine under different irrigation regimes. J. Exp. Bot. 58, 815-825.

Guerra, B., Steenwerth, K., 2012. Influence of floor management technique on grapevine growth, disease pressure, and juice and wine composition: a review. Am. J. Enol. Vitic. 63 (2), 149-164.

Hannah, L., Roehrdanz, P.R., Ikegami, M., Shepard, A.V., Shaw, M.R., Tabor, G., Hijmans, R.J., 2013. Climate change, wine, and conservation. Proc. Natl. Acad. Sci. U. S. A. 110 (17), 6907-6912.

Herath, I., Green, S., Singh, R., Horne, D., van der Zijpp, S., Clothier, B., 2013. Water footprinting of agricultural products: a hydrological assessment for the wate footprint of New Zealand's wines. J. Cleaner Prod. 41, 232-243.

Hochberg, U., Degu, A., Cramer, G.R., Rachmilevitch, S., Fait, A., 2015. Cultivar specific metabolic changes in grapevines berry skins in relation to deficit irrigation and hydraulic behavior. Plant Physiol. Biochem. 88, 42-52.

INE, 2010. Recenseamento Agricola 2009. Instituto Nacional de Estatística.

Intrigliolo, D., Castel, J., 2008. Effects of irrigation on the performance of grapevine cv.Tempranillo in Requena, Spain. Am. J. of Enol.Vitic. 59, 30-38.

IPCC, 2013. In: Stocker, T.F., Qin, D., Plattner, G.-K., Tignor, M., Allen, S.K., Boschung, J., Nauels, A., Xia, Y., Bex, V., Midgley, P.M. (Eds.), Climate Change 2013: The Physical Science Basis. I Contribution of Working Group I to the Fifth Assessment Report of the Intergovernmental Panel on Climate Change. Cambridge University Press, Cambridge, UK and New York, NY, USA, p. 1535.

ISO, 2006. ISO standards for life cycle assessment to promote sustainable development. International Organization for Standardization. http://www.iso. org/iso/home/news_index/news_archive/news.htm?refid=Ref1019.

IVV, 2015. Instituto da Vinha e do Vinho. Portugal. http://www.ivv.minagricultura.pt/np4/36. 
Hoekstra, A.Y., Mekonen, M.M., 2012. The water footprint of humanity. Proc Natl. Acad Sci U. S. A. 109 (9), 3232-3237.

Hoekstra, A.Y., Chapagain, A.K., Aldaya, M.M., Mekonnen, M.M., 2011. The Water Footprint Assessment Manual: Setting the Global Standard. Earthscan, London.

Jones, H.G., Grant, O.M., 2015. Remote sensing and other imaging technologies to monitor grapevine performance. In: Gerós, H., Chaves, M., Medrano, H., Delrot, S. (Eds.), Grapevine under Environmental Stress: from Ecophysiology to Molecular Mechanisms. Wiley-Blackwell, Hoboken, New Jersey.

Jones, G.V., White, M.A., Cooper, O.R., Storchmann, K., 2005. Climate change and global wine quality. Clim. Change 73 (3), 319-343.

Kang, S., Zhang, J., 2004. Controlled alternate partial root-zone irrigation: its physiological consequences and impact on water use efficiency. J. Exp. Bot. 55, 2437-2446

Kicherer, A., Roscher, R., Herzog, K., Šimon, S., Förstner Töpfer, W.R., 2013. BAT (Berry Analysis Tool): a high-throughput image interpretation tool to acquire the number, diameter, and volume of grapevine berries. Vitis 52 (3), 129-135.

Kicherer, A., Herzog, K., Pflanz, M., Wieland, M., Rüger, P., Kecke, S., Töpfer, R., 2015 An automated field phenotyping pipeline for application in grapevine research. Sensors 15 (3), 4823-4836.

Koundouras, S., Tsialtas, I.T., Zioziou, E., Nikolaou, N., 2008. Rootstock effects on the adaptive strategies of grapevine (Vitis vinifera L. cv. Cabernet-Sauvignon) under contrasting water status: leaf physiological and structural responses. Agric. Ecosyst. Environ. 128 (1), 86-96.

Knipfer, T., Eustis, A., Brodersen, C., Walker, A.M., Mcelrone, A.J., 2014. Grapevine species from varied native habitats exhibit differences in embolism formation/repair associated with leaf gas exchange and root pressure. Plant Cell Environ., http://dx.doi.org/10.1111/pce.12497.

Lamastra, L., Suciu, N.A., Novelli, E., Trevisan, M., 2014. A new approach to assessing the water footprint of wine: An Italian case study. Sci. Total Environ. 490, 748-756.

Lange, M.A., Poszig, D., Donta, A.A., 2005. Sustainable water management on mediterranean islands: research and education. Water Encyclopedia, http://dx. doi.org/10.1002/047147844X.wr149.

Lazarova, V., Levine, B., Sack, J., Cirelli, G., Jeffrey, P., Muntau, H., Brissaud, F., 2001 Role of water reuse for enhancing integrated water management in Europe and Mediterranean countries. Water Sci. Technol. 43 (10), 25-33.

Leddy, M.A., 2013. Investigating the relationship between wine tourism and proactive Environmental Management at wineries. In: MSc Thesis. Simon Fraser University, Canada, http://academyofwinebusiness.com/wp-content/ uploads/2013/04/Leddy-Williams. p. 74.

Lereboullet, A.L., Beltrando, G., Bardsley, D.K., 2012. Climate change and viticulture in Mediterranean climates: the complex response of socio-ecosystems. A comparative case study from France and Australia (1955-2040). EGU General Assembly Conference Abstracts, Vol. 14, p. 194.

Lereboullet, A.L., Bardsley, D., Beltrando, G., 2013a. Assessing vulnerability and framing adaptive options of two Mediterranean wine growing regions facing climate change: Roussillon (France) and McLaren Vale (Australia). EchoGéo, 23.

Lereboullet, A.L., Beltrando, G., Bardsley, D.K., 2013b. Socio-ecological adaptation to climate change: A comparative case study from the Mediterranean wine industry in France and Australia. Agric. Ecosyst. Environ. 164, 273-285.

Lionello, P., Abrantes, F., Gacic, M., Planton, S., Trigo, R., Ulbrich, U., 2014. The climate of the Mediterranean region: research progress and climate change impacts. Reg. Environ. Change 14 (5), 1679-1684.

Lopes, C.M., Monteiro, A., Rückert, F.E., Gruber, B., Steinberg, B., Schultz, H.R., 2004. Transpiration of grapevines and co-habitating cover crop and weed species in a vineyard A snapshot at diurnal trends. Vitis 43, 111-117.

Lopes, C., Costa, J.M., Monteiro, A., et al., 2014. Varietal behaviour under water and heat stress. In: Proceedings of the Congress of OENOVITI International Network, Germany, 3-4 November 2014, pp. 50-56.

Lopes, C.M., Santos, T.P., Monteiro, A., Rodrigues, M.L., Costa, J.M., Chaves, M.M., 2011. Combining cover cropping with deficit irrigation in a Mediterranean low vigor vineyard. Sci. Hortic. 129 (4), 603-612.

Lovisolo, C., Perrone, I., Carra, A., et al., 2010. Drought-induced changes in development and function of grapevine (Vitis spp.) organs and in their hydraulic and non hydraulic interactions at the whole plant level: a physiological and molecular update. Funct. Plant Biol. 37, 98-116.

Maes, W.H., Achten, W.M.J., Muys, B., 2009. Use of inadequate data and methodological errors lead to an overestimation of the water footprint of Jatropha curcas. Proc. Natl. Acad. Sci. U. S. A. 106 (34), E91.

MAGRAMA, 2014. Ministerio de Agricultura, Alimentación y Medio Ambiente. http://www.magrama.gob.es.

Martins, A., 2011. Selecting Grapevine varieties, a history with its roots in the regions of the Douro and Vinho Verde. In: Girão, Francisco (Ed.), An Innovator in Vitiviniculture in the North of Portugal, II. Fundação Francisco, Girão, Portugal, pp. 205-229.

Martorell, S., 2014. Understanding the regulation of leaf and plant gas exchange under water stress with a process-based model of stomatal conductance. In: Ph.D. Thesis. Consejo Superior de Investigaciones Cientificas, Universitat de les Illes Baleares, p. 228.

Martorell, S., Diaz-Espejo, A., Tomàs, M., Pou, A., El Aou-ouad, H., Escalona, J.M., Medrano, H., 2015. Differences in water-use-efficiency between two Vitis vinifera cultivars (Grenache and Tempranillo) explained by the combined response of stomata to hydraulic and chemical signals during water stress. Agric. Water Manag. 156, 1-9.
Matese, A., Toscano, P., Di Gennaro, S.F., Genesio, L., Vaccari, F.P., Primicerio, J., Gioli, B., 2015. Intercomparison of UAV, Aircraft and Satellite Platforms for Precision Viticulture. Remote Sensing 7 (3), 2971-2990.

Maton, L., Leenhardt, D., Goulard, M., Bergez, J.E., 2005. Assessing the irrigation strategies over a wide geographical area from structural data about farming systems. Agric. Syst. 86, 293-311.

Matzner, S., Comstock, J., 2001. The temperature dependence of shoot hydraulic resistance: implications for stomatal behaviour and hydraulic limitation. Plant Cell Environ. 24, 1299-1307.

Marshall, R.S., Cordano, M., Silverman, M., 2005. Exploring individual and institutional drivers of proactive environmentalism in the US wine industry. Bus. Strategy Environ. 14 (2), 92-109.

Mazzeto, F., Calcante, A., Vercesi, A., 2010. Integration of optical and analogue sensors for monitoring canopy health and vigour in precision viticulture. Precis. Agric. 11 (6), 636-649.

Medellin-Azuara, J., Mendoza-Espinosa, L.G., Pells, C.M., Lund, J.R., 2013. Pre-Feasibility Assessment of a Water Fund for the Ensenada Region: Infrastructure and Stakeholder Analyses. A Report for The Nature Conservancy. Prepared by the Center for Watershed Sciences, UC, Davis, p. 91.

Medrano, H., Escalona, J.M., Cifre, J., Bota, J., Flexas, J., 2003. A ten-year study on the physiology of two Spanish grapevine cultivars under field conditions: effects of water availability from leaf photosynthesis to grape yield and quality. Func. Plant Biol. 30 (6), 607-619.

Medrano, H., Tomás, M., Martorell, S., Escalona, J.M., Pou, A., Fuentes, S., Bota, J., 2014. Improving water use efficiency of vineyards in semi-arid regions. A review. Agron. Sust. Dev., 1-19.

Medrano, H., Tomás, M., Martorell, S., Flexas, J., Hernández, E., Rosselló, J., Pou, A. Escalona, J.M., Bota, J., 2015. From leaf to whole plant water use efficiency (WUE) in complex canopies: limitations of leaf WUE as selection target. The Crop J. 3 (3), 220-228.

MED-EUWI, 2007. Mediterranean Wastewater Reuse Report, Mediterranean wastewater reuse working group (MED WWR WG). November 2007. http://ec europa.eu/environment/water/water-urbanwaste/info/pdf/final_report.pdf.

Monteiro, A., Lopes, C.M., 2007. Influence of cover crop on water use and performance of vineyard in Mediterranean Portugal. Agric. Ecosyst. Environ. $121,336-342$.

Mori, K., Goto-Yamamoto, N., Kitayama, M., Hashizume, K., 2007. Loss of anthocyanins in red-wine grape under high temperature. J. Exp. Bot. 58 (8), 1935-1945.

Nardini, A., Pedà, G., Rocca, N.L., 2012. Trade-offs between leaf hydraulic capacity and drought vulnerability: morpho-anatomical bases, carbon costs and ecological consequences. New Phytol. 196 (3), 788-798.

Notarnicola, B., Hayashi, K., Curran, M.A., Huisingh, D., 2012. Progress in working towards a more sustainable agri-food industry. J. Cleaner Prod. 28, 1-8.

OECD, 2010. Pricing Water Resources and Water and Sanitation Services. OECD, Paris, France.

Palliotti, A., et al., 2014. Morpho-structural and physiological response of container-grown Sangiovese and Montepulciano cvv. (Vitis vinifera) to re-watering after a pre-veraison limiting water deficit. Funct. Plant Biol. 41, 634-647.

Pantin, F., Monnet, F., Jannaud, D., Costa, J.M., Renaud, J., Muller, B., Genty, B., 2013. The dual effect of abscisic acid on stomata. New Phytol. 197 (1), 65-72.

Paranychianakis, N.V., Nikolantonakis, M., Spanakis, Y., Angelakis, A.N., 2006. The effect of recycled water on the nutrient status of Soultanina grapevines grafted on different rootstocks. Agric. Water Manag. 81 (1), 185-198.

Pavloušek P., 2013. Tolerance to Lime-induced Chlorosis and Drought in Grapevine Rootstocks. INTECH Open Access Publisher. http://cdn.intechopen.com/pdfswm/41400.pdf

Perrone, I., Pagliarani, C., Lovisolo, C., Chitarra, W., Roman, F., Schubert, A., 2012. Recovery from water stress affects grape leaf petiole transcriptome. Planta 235 (6), 1383-1396.

Perry, C., 2014. Water footprints: path to enlightenment, or false trail? Agric Water Manag. 134, 119-125.

Peterson, G.A., Lyon, D.J., Fenster, C.R., 2012. Valuing long-term field experiments:quantifying the scientific contribution of a long-term tillage experiment. Soil Sci. Soc. Am. J. 76, 757-765.

Point, E., Tyedmers, P., Naugler, C., 2012. Life cycle environmental impacts of wine production and consumption in Nova Scotia, Canada. J. Cleaner Prod. 27, 11-20.

Pou, A., Flexas, J., Alsina, M.M., Bota, J., Carambula, C., de Herralde, F., Galmés, J. Lovisolo, C., Jiménez, M., Ribas-Carbo, M., Rusjan, D., Secchi, F., Tomàs, M., Zsófi, Z., Medrano, H., 2008. Adjustments of water-use efficiency by stomatal regulationduring drought and recovery in the drought-adapted Vitis hybrid Richter-110 (V. berlandieri $¥ V$. rupestris). Physiol. Plant. 134, 313-323.

Pou, A., Gulias, J., Moreno, M., Tomas, M., Medrano, H., Cifre, J., 2011 Cover cropping in Vitis vinifera L. cv. Manto negro vineyards under Mediterranean conditions: effects on plant vigour, yield and grape quality. J. Int. Sci. Vign. Vin. $45,223-234$

Pou, A., Medrano, H., Flexas, J., Tyerman, S.D., 2013. A putative role for TIP and PIP aquaporins in dynamics of leaf hydraulic and stomatal conductances in grapevine underwater stress and re-watering. Plant Cell Environ. 36 (4), 828-843.

Pou, A., Medrano, H., Tomàs, M., Martorell, S., Ribas-Carbó, M., Flexas, J., 2012. Anisohydric behaviour in grapevines results in better performance under moderate water stress and recovery than isohydric behaviour. Plant Soil 359 (1-2), 335-349. 
Prichard, T., 1998. Water use and infiltration. In: Chuck Ingels, et al. (Eds.), Cover Cropping in Vineyards: A Grower's Handbook. University of California, Division of Agriculture and Natural Resources, Publication 3338, Oakland, CA, pp. 86-90.

Pullman, M.E., Maloni, M.J., Dillard, J., 2010. Sustainability practices in food supply chains: how is wine different? J. Wine Res. 21 (1), 35-56.

Radke, J, Pinto, P., Lachhwani, K, Kondolf, G.M., Rocha, J, Llobet, A.S., Edwards, D., Francella, V., Jurich, K., McKnight, K., Alex, R.A., Eng, T., Harrell, B., Uennatornwaranggoon, F., Wolfson, E., Alfaro, P.J., Ding, E., Marzion, R., 2015. Alqueva Changing Ecologies of the Montado Landscape, Alentejo, Portugal. http://ced.berkeley.edu/downloads/research/AlquevaReportLA205-2015.pdf

Raso, J., 2013. Update of the Final Report on Wastewater Reuse in the European Union. Project: Service Contract for the Support to the Follow-up of the Communication on Water Scarcity and Droughts. TYPSA Consulting Engineers and Architects, Barcelona, Spain.

Retallack, M., 2012. What can be done in the vineyard to manage risk in difficult seasons? Aust. New Zealand Grapegrower WineMaker 586, 30-37.

Retallack, M., 2013. Assessing yield water use efficieny (WUE) in the Murray Valley and Riverina wine regions. http://mvwi.com.au/items/577/ MVWI\%20\%20Riverina\%20WUE\%20Report\%202012-13.pdf. p. 44.

Reynolds, M.P., Nagarajan, S., Razzaque, M.A., Ageeb, O.A.A., 2001. Heat tolerance. In: Reynolds, M.P., Ortiz-Monasterio, J.I., McNab, A. (Eds.), Application of Physiology in Wheat Breeding. CIMMYT, México DF, pp. 88-100.

Roelfsema, M.R., Kollist, H., 2013. Tiny pores with a global impact. New Phytol. 197 (1), 11-15.

Rogiers, S.Y., Smith, J.P., Holzapfel, B.P., Hardie, W.J., 2011. Soil temperature moderates grapevine carbohydrate reserves after bud-break and conditions fruit set responses to photoassimilatory stress. Funct. Plant Biol. 38, 899-909.

Rogiers, S.Y., Clarke, S.J., 2013. Nocturnal and daytime stomatal conductance respond to root-zone temperature in 'Shiraz'grapevines. Ann. Bot. 111 (3) 433-444.

Rolli, E., Marasco, R., Vigani, G., Ettoumi, B., Mapelli, F., Deangelis, M.L., Daffonchio, D., 2014. Improved plant resistance to drought is promoted by the root-associated microbiome as a water stress-dependent trait. Environ. Microbiol. 17 (2), 316-331.

Romero, P., Fernández-Fernández, J.I., Martinez-Cutillas, A., 2010. Physiological thresholds for efficient regulated deficit-irrigation management in winegrapes grown under semiarid conditions. Am. J. Enol.Vitic. 61 (3), 300-312.

Romero, P., Dodd, I., Martinez-Cutillas, A., 2012. Contrasting physiological effects of partial root zone drying in field-grown grapevine (Vitis vinifera L. cv. Monastrell) according to total soil water availability. J Exp. Bot. 63 (11), 4071-4083.

Ruggieri, L., Cadena, E., Martínez-Blanco, J., Gasol, C.M., Rieradevall, J., Gabarrell, X Sánchez, A., 2009. Recovery of organic wastes in the Spanish wine industry. Technical, economic and environmental analyses of the composting process. J Cleaner Prod. 17 (9), 830-838.

Rustioni, L., Rocchi, L., Guffanti, E., Cola, G., Failla, O., 2014. Characterization of grape (Vitis vinifera L.) berry sunburn symptoms by reflectance. J. Agric. Food Chem. 62 (14), 3043-3046.

Santini, C., Cavicchi, A., Casini, L., 2013. Sustainability in the wine industry: key questions and research trends. Agric. Food Econ. 1 (1), 1-14.

Santos, T.P., Lopes, C.M., Rodrigues, M.L., de Souza, C.R., Maroco, J.P., Pereira, J.S., Chaves, M.M., 2003. Partial rootzone drying: effects on growth and fruit quality of field-grown grapevines (Vitis vinifera). Funct. Plant Biol. 30 (6), 663-671.

SARDI, 2009. Irrigating with reclaimed water-a scoping study to investigate feasibility for the wine industry. http://research.agwa.net.au/wp-content/ uploads/2012/09/SAR-07-01-Final-Report.pdf.

Schultz, H.R., 2003. Differences in hydraulic architecture account for near-isohydric and anisohydric behaviour of two field-grown Vitis vinifera $\mathrm{L}$. cultivars during drought. Plant Cell Environ. 26, 1393-1405.

Schultz, H.R., Stoll, M., 2010. Some critical issues in environmental physiology of grapevines: future challenges and current limitations. Aust. J. Grape Wine Res. $16,4-24,1$.

Sack, L., Scoffoni, C., 2012. Measurement of leaf hydraulic conductance and stomatal conductance and their responses to irradiance and dehydration using the Evaporative Flux Method (EFM). J. Visualized Exp. JoVE, 70.

Sadras, V.O., Moran, M.A., 2012. Elevated temperature decouples anthocyanins and sugars in berries of Shiraz and Cabernet Franc. Aust. J. Grape Wine Res. 18, $115-122$.

Schachtman, D.P., Goodger, J.Q., 2008. Chemical root to shoot signaling under drought. Trends Plant Sci. 13 (6), 281-287.

Schroeder, J.I., Allen, G.J., Hugouvieux, V., Kwak, J.M., Waner, D., 2001. Guard cell signal transduction. Annu. Rev. Plant Physiol. Plant Mol. Biol. 52, 627-658. Seguin, B., 2010. Coup de Chaud Sur L'agriculture. Collection Changer d'ère. Delachaux et Niestlé, Paris, p. 207.

Serra, I., Strever, A., Myburgh, P.A., Deloire, A., 2014. Review: the interaction between rootstocks and cultivars (Vitis vinifera L.) to enhance drought tolerance in grapevine. Aust. J. Grape Wine Res. 20 (1), 1-14.

Sinclair, T.R., Bingham, G.E., Lemon, E.R., Allen Jr., L.H., 1975. Water use efficiency of field grown maize during moisture stress. Plant Physiol. 56, 245-249.

Sinha, P., Akoorie, M.E., 2010. Sustainable environmental practices in the New Zealand wine industry: an analysis of perceived institutional pressures and the role of exports. J. Asia-Pacific Bus. 11 (1), 50-74.

Skewes, M., 1998. Irrigation benchmarking for winegrapes. Aust Grape. Wine. 61-64, Skewes, M., Meissner, A.P., 1997. Irrigation benchmarks and best management practices for winegrapes. Primary Industries and Resources SA Technical Report.
Smart, R.E., 1985. Principles of grapevine canopy microclimate manipulation with implications for yield and quality. A review. Am. J. Enol.Vitic. 36 (3), 230-239.

Soar, C.J., Dry, P.R., Loveys, B.R., 2006. Scion photosynthesis and gas-exchange in Vitis vinifera L. cv Shiraz mediation of rootstock effects via xylem sap ABA. Aust. J. Grape Wine Res. 12, 82-96.

Soliman, A., Heck, R.J., Brenning, A., Brown, R., Miller, S., 2013. Remote sensing of soil moisture in vineyards using airborne and ground-based thermal inertia data. Remote Sens. 5, 3729-3748.

Souza, C.R., Maroco, J.P., dos Santos, T.P., Rodrigues, M.L., Lopes, C., Pereira, J.S., Chaves, M.M., 2005. Control of stomatal aperture and carbon uptake by deficit irrigation in two grapevine cultivars. Agric. Ecosyst. Environ. 106 (2), 261-274.

Spayd, S.E., Tarara, J.M., Mee, D.L., Ferguson, J.C., 2002. Separation of sunlight and temperature effects on the composition of Vitis vinifera cv. Merlot berries. Amer. J. Enol Vitic. 53 (3), 171-182.

Stigter, T.Y., 2012. Restoration of groundwater quality to sustain coastal ecosystems productivity. In: Wolanski, E., McLusky, D.S. (Eds.), Treatise on Estuarine and Coastal Science, 10. Academic Press, Waltham, pp. 245-262.

Strano, A., De Luca, A.I., Falcone, G., Iofrida, N., Stillitano, T., Gulisano, G., 2013. Economic and environmental sustainability assessment of wine grape production scenarios in Southern Italy. Agric Sci. 4 (05), 12.

Szolnoki, G., 2013. A cross-national comparison of sustainability in the wine industry. J. Cleaner Prod. 53, 243-251.

SUSTAVINO, 2012. SUSTAVINO Project Report Summary, Project ref: 218472, FP7-SME, (www.nzwine.com/sustentability).

Tambussi, E.A., Bort, J., Araus, J.L., 2007. Water use efficiency in C3 cereals under Mediterranean conditions: a review of physiological aspects. Ann. Appl. Biol. $150,307-321$.

Tapia, A.M., Cabezas, J.A., Cabello, F., Lacombe, T., Martínez-Zapater, J.M., Hinrichsen, P., Cervera, M.T., 2007. Determining the Spanish origin of representative ancient American grapevine varieties. Am. J. Enol. Vitic. 58, $242-251$.

Tandonnet, J.P., Cookson, S.J., Vivin, P., Ollat, N., 2010. Scion genotype controls biomass allocation and root development in grafted grapevine. Aust. J. Grape Wine Res. 16 (2), 290-300.

Tardieu, F., Simonneau, T., Parent, B., 2015. Modelling the coordination of the controls of stomatal aperture, transpiration, leaf growth, and abscisic acid: update and extension of the Tardieu-Davies model. J. Exp. Bot. 66 (8), 2227-2237.

Teixeira, A., Eiras-Dias, J., Castellarin, S.D., Gerós, H., 2013. Berry phenolics of grapevine under challenging environments. Int. J. Mol. Sci. 14 (9), 18711-18739.

Teodosiu, C., Barjoveanu, G., Robu, B., Ene, S.A., 2012. Sustainability in the wate use cycle: challenges in the Romanian context. Environ. Eng. Manag. J. 11 (11), 1987-2000.

Teskey, R., Wertin, T., Bauweraerts, I., Ameye, M., McGuire, M.A., Steppe, K., 2014 Responses of tree species to heat waves and extreme heat events. Plant Cell Environ. 38, 1699-1712.

Tomás, M., Medrano, H., Pou, A., Escalona, J.M., Martorell, S., Ribas-Carbó, M., Flexas, J., 2012. Water use efficiency in grapevine cultivars grown under controlled conditions: effects of water stress at the leaf and whole-plant level. Aust. J Grape. Wine. Res. 18 (2), 164-172.

Tomás, M., Medrano, H., Escalona, J.M., Martorell, S., Pou, A., Ribas-Carbó, M., Flexas, J., 2014a. Variability of water use efficiency in grapevines. Environ. Exp. Bot. 103, 148-157.

Tomás, M., Medrano, H., Brugnoli, E., Escalona, J.M., Martorell, S., Pou, A., Ribas-Carbó, M., Flexas, J., 2014b. Variability of mesophyll conductance in grapevine cultivars under water stress conditions in relation to leaf anatomy and water use efficiency. Aust. J. Grape Wine Res. 20, 272-280.

Tombesi, S., Nardini, A., Farinelli, D., Palliotti, A., 2014. Relationships between stomatal behavior, xylem vulnerability to cavitation and leaf water relations in two cultivars of Vitis vinifera. Physiol. Plant. 152 (3), 453-464.

Torrellas, M., Antón, A., Montero, J.I., 2013. An environmental impact calculator for greenhouse production systems. J. Environ. Manag. 118, 186-195.

Torres-Ruiz, J.M., Diaz-Espejo, A., Perez-Martin, A., Hernandez-Santana, V., 2014. Role of hydraulic and chemical signals in leaves, stems and roots in the stomatal behaviour of olive trees under water stress and recovery conditions. Tree Physiol., 415-424.

Tramontini, S., van, L., eeuwen, C., Domec, J., Destrac-Irvine, A., Basteau, C., Vitali, M., Mosbach-Schulz, O., Lovisolo, C., 2013. Impact of soil texture and water availability on the hydraulic control of plant and grape-berry development. Plant Soil 368, 215-230.

Tsegay, D., Amsalem, D., Almeida, M., Crandles, M., 2014. Responses of grapevine rootstocks to drought stress. Int. J. Plant Physiol. Biochem. 6 (1), 1-6.

USDA, 2013. EU_27 Wine Annual Report and Statistics. Gain Report Number IT1307. http://gain.fas.usda.gov/Recent\%20GAIN\%20Publications/ Wine\%20Annual_Rome_EU-27_2-22-2013.pdf

USDA, 2014. Eu-28 Wine Annual Report and Statistics 2014. Wine annual. http:/ gain.fas.usda.gov/Recent\%20GAIN\%20Publications/Wine\%20Annual_Rome_EU 28_2-26-2014.pdf

Valverde, P., Carvalho, M., Serralheiro, R., Maia, R., Ramos, V., Oliveira, B., 2015. Climate change impacts on rainfed agriculture in the Guadiana river basin (Portugal). Agric. Water Manag. 150, 35-45.

Vandeleur, R.K., Mayo, G., Shelden, M.C., Gilliham, M., Kaiser, B.N., Tyerman, S.D., 2009. The role of plasma membrane intrinsic protein aquaporins in wate transport through roots: diurnal and drought stress responses reveal different 
strategies between isohydric and anisohydric cultivars of grapevine. Plant Physiol. 149 (1), 445-460.

Vanham, D., Bidoglio, G., 2013. A review on the indicator water footprint for the EU28. Ecol. Indicat. 26, 61-75.

Viers, J.H., Williams, J.N., Nicholas, K.A., Barbosa, O., Kotzé, I., Spence, L., Reynolds, M., 2013. Vinecology: pairing wine with nature. Conserv. Lett. 6 (5), 287-299. Villarejo, C., Lopez, C., 2014. Water use in arid rural systems and the integration of water and agricultural policies in Europe: the case of Andarax river basin. Environ. Dev. Sustain. 16 (4), 957-975.

Walker, R, Boland, A., 2004. Improving water use efficiency in viticulture in the Murray Darling Basin http://citeseerx.ist.psu.edu/viewdoc/download?doi=10. 1.1.471.3486\&rep=rep $1 \&$ type=pdf.

WATERWIKI. 2015. http://www.iwawaterwiki.org/xwiki/bin/view.

Zarco-Tejada, P.J., Berni, J.A.J., Suárez, L., Sepulcré-Cantó, G., Morales, F., Miller, R.J., 2009. Imaging chlorophyll fluorescence with an airborne narrow-band multispectral camera for vegetation stress detection. Remote Sens. Environ. $113,1262-1275$
Zarco-Tejada, P.J., González-Dugo, V., Berni, J.A., 2012. Fluorescence, temperature and narrow-band indices acquired from a UAV platform for water stress detection using a micro-hyperspectral imager and a thermal camera. Remote Sens. Environ. 117, 322-337.

Zucca, G., Smith, D.E., Mitry, D.J., The, 2009. Sustainable viticulture and winery practices in California: what is it, and do customers care? Int. J. Wine Res. 2 , 189-194.

Zufferey, V., Cochard, H., Ameglio, T., Spring, J.L., Viret, O., 2011. Diurnal cycles of embolism formation and repair in petioles of grapevine (Vitis vinifera cv. Chasselas). J. Exp. Bot. 62 (July (11)), 3885-3894.

Zarrouk, O., Costa, J.M., Francisco, R., Lopes, C., Chaves, M.M., 2014. Drought and water management in Mediterranean vineyards. In: Hernâni Gerós, Manuela Chaves, Serge Delrot, Hipolito Medrano (Eds.), Grapevine under Environmenta Stress: from Ecophysiology to Molecular Mechanisms. Wiley Blackwel, in press. 